\title{
1 A multi-proxy approach to decode the end-Cretaceous \\ 2 mass extinction
}

3 Jahnavi Punekar ${ }^{1}$, Gerta Keller ${ }^{1}$, Hassan M. Khozyem ${ }^{2}$, Thierry Adatte ${ }^{3}$, Eric Font ${ }^{4}$, Jorge

$4 \quad$ Spangenberg ${ }^{3}$

5

$6 \quad{ }^{1}$ Geosciences, Princeton University, Princeton, NJ 08540, USA.

$7 \quad{ }^{2}$ Department of Geology, Faculty of Science, Aswan University, Aswan 81528, Egypt.

$8{ }^{3}$ Institute of Earth Sciences, University of Lausanne, 1015 Lausanne, Switzerland.

$9{ }^{4}$ IDL-FCUL, Instituto Dom Luís, Faculdade de Ciências, Universidade de Lisboa, Portugal, Campo

10 Grande, 1749-016, Lisbon, Portugal.

12 Corresponding Author:

13 Jahnavi Punekar

14 Phone: +1 - 609-258-6482

15 Email: jpunekar@princton.edu

17 Abstract

18 Mass extinctions generally involve a complex array of interrelated causes and are

19 best evaluated by a multi-proxy approach as applied here for the end-Cretaceous mass

20 extinction. This study documents and compares the planktic foraminiferal records,

21 carbonate dissolution effects, stable isotopes, and magnetic susceptibility in France

22 (Bidart), Austria (Gamsbach) and Tunisia (Elles) in order to explore the environmental

23 conditions during the uppermost Maastrichtian Plummerita hantkeninoides zone CF1

24 leading up to the mass extinction. Planktic foraminiferal assemblages at Bidart and

25 Gamsbach appear to be more diverse than those at Elles, with unusually high abundance

$26(20-30 \%)$ and diversity ( 15 species) of globotruncanids in the two deep-water sections

27 but lower abundance $(<10 \%)$ and diversity ( $<10$ species) at the middle shelf Elles section. 
28 Oxygen isotopes in zone CF1 of Elles record rapid climate warming followed by cooling

29 and a possible return to rapid warming prior to the mass extinction.

30 The onset of high stress conditions for planktic foraminifera is observed $\sim 50-60$

$31 \mathrm{~cm}$ below the KTB at Bidart and Gamsbach, and $\sim 4.5 \mathrm{~m}$ below the KTB at Elles due to

32 much higher sediment accumulation rates. These intervals at Bidart and Gamsbach record

33 low magnetic susceptibility and high planktic foraminiferal fragmentation index (FI) at

34 Elles, Bidart and Gamsbach. An increased abundance of species with dissolution-resistant

35 morphologies is also observed at Gamsbach. The correlative interval in India records

36 significantly stronger carbonate dissolution effects in intertrappean sediments between

37 the longest lava flows, ending with the mass extinction. Based on current evidence, this

38 widespread dissolution event stratigraphically coincides with the climate cooling that

39 follows the Late Maatrichtian global warming and may be linked to ocean acidification

40 due to Deccan volcanism. The estimated 12,000-28,000 Gigatons (Gt) of $\mathrm{CO}_{2}$ and 5200-

$4113,600 \mathrm{Gt}$ of $\mathrm{SO}_{2}$ introduced into the atmosphere likely triggered the carbonate crisis in

42 the oceans resulting in severe stress for marine calcifiers leading to the mass extinction. 


\section{1. INTRODUCTION}

45

46

50 Haslett, 1994). At this locality about $8 \mathrm{~m}$ of uppermost Maastrichtian and $\sim 4 \mathrm{~m}$ of basal

51 Danian sediments are exposed, including the boundary clay, an Iridium (Ir) anomaly and

52 negative $\delta^{13} \mathrm{C}$ excursion that indicate a relatively complete KTB transition (Fig. 2A, C;

53 Renard et al., 1982; Bonté et al., 1984; Apellaniz et al., 1997; Font et al., 2014).

54 Nevertheless, the Bidart section remained in limbo for nearly two decades because of

55 uncertain age control, particularly the reported absence of the latest Maastrichtian

56 nannofossil Micula prinsii zone and absence of the planktic foraminiferal zones CF1

57 (Plummerita hantkeninoides) and CF2, which together are correlative with paleomagnetic

58 chron C29r. This led to the assumption that the latest Maastrichtian is missing (Gallala et

59 al., 2009). Subsequent paleomagnetic and microfossil studies revealed that the $\sim 8 \mathrm{~m}$ of

60 uppermost Maastrichtichtian sediments below the KTB were deposited during the Micula

61 prinsii zone (Galbrun and Gardin, 2004) and the recent finding of P. hantkeninoides zone

62 CF1 (Font et al., 2014) further confirms deposition in paleomagnetic chron C29r below

63 the KTB boundary and hence a substantially complete KTB transition.

64 Restudy of the Bidart section is particularly important because of the potential 65 connection between the high-stress interval spanning the last 50-cm of the Maastrichtian 66 and Deccan volcanism in India (Font et al., 2011, 2014). As early as the 1990s, Apellaniz 67 et al. (1997) reported a drop in carbonate content and increased planktic foraminiferal test 
68 dissolution particularly in the KTB clay and the underlying 28-cm uppermost

69 Maastrichtian sediments. This interval depleted in carbonate content is also featured by a

70 loss of iron oxides (biogenic and detrital magnetite), interpreted to be the result of

71 acidification linked to Deccan acid rains (Font et al., 2014; Font and Abrajevitch, 2014).

72 The possible link between this dissolution interval and ocean acidification related to

73 Deccan volcanism appears to be more than coincidental and warrants a fresh

74 investigation of associated changes in planktic foraminiferal assemblages. Bidart

75 therefore provides a unique opportunity to analyze this critical time interval in Earth

76 history to understand the environmental changes in the northern mid-latitude Atlantic

77 Ocean that may be related to the global effects of Deccan volcanism.

78 Preliminary faunal analysis of the Bidart section reveals a planktic foraminiferal

79 assemblage remarkably different from those reported for El Kef (GSSP) and Elles,

80 Tunisia, and other continental shelf locations (Abramovich et al., 2002; Font et al., 2014).

81 To evaluate whether this is due to different depositional settings (open ocean bathyal

82 depths for Bidart versus shelf depth for Tunisia), we chose a second bathyal section,

83 Gamsbach, Austria, as a control site. Gamsbach is located in the Eastern Alps with a

84 palaeogeographic setting and depositional history similar to Bidart (Figs. 1, 3B; Grachev

85 et al., 2005). Gamsbach contains planktic foraminiferal assemblages similar to those at

86 Bidart, including a pre-KTB dissolution interval that supports the choice of Gamsbach as

87 a complementary site.

88 Although numerous studies have explored the KTB transition at Bidart and

89 Gamsbach over the past three decades (see sections 1 and 2, supplementary material), the

90 published microfossil records are generally not quantitative and at very low sample 
91 resolution yielding little or no information for the critical pre-extinction interval. We

92 present comprehensive biostratigraphic, assemblage and stable isotope, geochemical and

93 mineralogical data that focus on the rapid climatic and biotic events of zone CF1, which

94 globally record the crises that led up to the KTB mass extinction. The primary objective

95 of this study is to test the hypothesis that Deccan volcanism may have caused global

96 climate changes and ocean acidification that directly resulted in the KTB mass extinction

97 recorded in planktic foraminifera.

98 We test this hypothesis based on: (1) High-resolution quantitative planktic

99 foraminiferal species abundances through the uppermost Maastrichtian zones CF1-CF2 at

100 Bidart and Gamsbach. (2) High-resolution biostratigraphic analysis with special emphasis

101 on the presence/absence of index species (e.g., Gansserina gansseri and Plummerita

102 hantkeninoides) to re-evaluate the conflicting published reports (reviewed below). (3)

103 Evaluation of the palaeoclimatic and the paleoenvironmental conditions recorded in

104 stable isotopes, geochemical proxies, and associated biotic events. (4) Evaluation of

105 carbonate and iron oxide dissolution events based on the quality of foraminiferal test

106 preservation (fragmentation index FI) and magnetic susceptibility, respectively. (5)

107 Determination of the chronologic sequence of biotic, climatic and geochemical events

108 through zone $\mathrm{CF} 1$ at Bidart and Gamsbach, as well as their regional and global

109 oceanographic significance in the context of environmental perturbations related to

110 Deccan volcanism. And (6) comparison with shelf sequences at Elles and El Kef, Tunisia,

111 to assess the nature of environmental changes in shallow vs. deep-water environments.

\section{2. BACKGROUND}




\section{2.1. Bidart and Gamsbach}

116 Previous studies of the Bidart and Gamsbach sections report sedimentologic,

117 geochemical, paleomagnetic and microfossil biostratigraphic data. A brief summary is

118 given here (See supplementary material for details).

119 Bidart: Planktic foraminifera and nannofossils record a rapid decline at the KTB

120 at Bidart (Gorostidi and Lamolda, 1995; Thibault et al., 2004; Apellaniz et al., 1997;

121 Gallala et al., 2009), whereas benthic foraminifera switch from infaunal to epifaunal

122 dominance across the KTB (Alegret et al., 2004). An Iridium anomaly of $6.3 \pm 1.1 \mathrm{ppb}$,

123 enrichment of $\mathrm{Co}, \mathrm{Cr}, \mathrm{Ni}, \mathrm{As}, \mathrm{Sb}, \mathrm{Se}$ and depletion of rare earth elements (REE) are

124 reported in the Bidart KTB red clay layer (Delacotte, 1982; Smit and Ten Kate, 1982;

125 Bonté et al., 1984). Some studies report the presence of microtektites, microspherules and

126 Ni-rich crystals in the KTB red layer in the Basque sections but provide no supporting

127 data (Apellaniz et al., 1997; Arz and Arenillas, 1998; Arenillas et al., 2004).

128 Gamsbach: Previous studies on Gamsbach show the KTB clay enriched in Ir (6

$129 \mathrm{ppb}$ ), iron hydroxides, $\mathrm{Co}, \mathrm{Ni}, \mathrm{Cr}$ and siderophile elements and sporadic occurrence of

130 pure $\mathrm{Ni}$ crystals, awaruite $\left(\mathrm{Fe}_{3} \mathrm{Ni}\right), \mathrm{Ni}-\mathrm{Fe}, \mathrm{Ni}-\mathrm{Fe}-\mathrm{Mo}$ and $\mathrm{Ni}-\mathrm{Fe}-\mathrm{Co}$ alloys, cosmic dust

131 and spherules of varied geochemical affinities (Grachev et al., 2005, 2008; Pechersky et

132 al., 2006; Egger et al., 2009). Micropaleontological and biostratigraphic studies are

133 limited due to poor carbonate preservation throughout the KTB transition (Egger et al.,

134 2004, Summesberger et al., 2009, Korchagin and Kollmann in Grachev, 2009).

135 Summesberger et al. (2009) reported on the cephalopod, nannofossil and planktic

136 foraminiferal biostratigraphy at Gamsbach but provided no quantitative documentation. 


\section{2.2. Deccan Volcanism}

139 Deccan eruptions resulted in an estimated 1.5 million $\mathrm{km}^{3}$ of lava flooding the

140 Indian sub-continent (Raja Rao et al., 1999). Three main phases of eruptions are

141 recognized: the initial phase-1 ( $\sim 6 \%$ of the total volume) in the early late Maastrichtian

142 recently dated by ${ }^{40} \mathrm{Ar} /{ }^{39} \mathrm{Ar}$ at $67.12 \pm 0.44 \mathrm{Ma}$ at the chron $\mathrm{C} 30 \mathrm{n} / \mathrm{C} 29 \mathrm{r}$ transition

143 (Schoebel et al., 2014); the main phase-2 ( 80\% of the total lava pile) in chron C29r

144 (Subbarao et al., 2000; Jay and Widdowson, 2008; Chenet et al., 2007, 2008; Schoene et

145 al., 2014) culminating in the KTB mass extinction (Keller et al., 2011a, 2012); and the

146 final phase-3 ( 14\% of the total volume) in the early Danian chron C29n. The

147 environmental effects of the three Deccan phases are determined by the tempo and

148 magnitude of eruptions and the amounts of $\mathrm{SO}_{2}, \mathrm{CO}_{2}, \mathrm{Cl}$ and other gases released into the

149 atmosphere (Self et al., 2008). A global review of the planktic foraminiferal events

150 contemporaneous with Deccan phase-2 and phase-3 can be found in Punekar et al.

151 (2014a).

152 In the Krishna-Godavari Basin of SW India a rapid succession of four phase-2

153 lava mega-flows span C29r below the KTB and mark the CF1-CF2 and Micula prinsii

154 (nannofossil) zones; intertrappean sediments reveal rapid extinctions (Keller et al., 2011a,

155 2012). The correlative interval in Meghalaya (NE India) is dominated (95\%) by

156 Guembelitria blooms, and high-stress is also marked by ocean acidification and strong

157 carbonate dissolution (Gertsch et al., 2011). Schoene et al. (2015) show that the Phase-2

158 volcanism itself lasted $~ 500-k y r$ into the Danian. On a global basis paleoclimatic data

159 from DSDP 525A (Li and Keller, 1998a), Tunisia, (Stüben et al., 2003) and Texas (Keller 
160 et al., 2011b; Abramovich et al., 2011) show at least one and possibly multiple

161 hyperthermal events during the CF1-CF2 global warming, which indicates complex and

162 episodic climate fluctuations in the latest Maastrichtian correlative with Deccan phase-2

163 (Punekar et al., 2014a).

164 At Bidart and Gubbio Font et al. $(2011,2014)$ discovered akaganeite, an unusual

165 Cl-bearing iron hydroxide preserved in a low magnetic susceptibility (MS) interval below 166 the KTB. The origin of this low MS interval is explained by the loss of detrital and

167 biogenic magnetites from reductive iron hydroxide dissolution due to acid rains and 168 ocean acidification linked to Deccan Phase-2 (Font et al., 2014). They proposed a Deccan

169 volcanic origin for akaganeite, formed by interaction of acid aerosols with the high 170 atmosphere and potentially transported through the stratosphere at Bidart (Atlantic realm)

171 and Gubbio, Italy (Tethys realm). If a volcanic origin for akaganeite is confirmed, this

172 can provide a promising new geochemical benchmark for identifying Deccan 173 environmental effects across the globe.

175 3. GEOLOGIC SETTING AND LITHOLOGY

177 3.1. Bidart, France

178 The Bidart KTB boundary section outcrops along the Erreteguia beach $2 \mathrm{~km}$ north

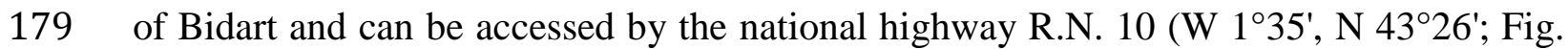

180 2B). Sediments consist of hemipelagic to pelagic marls and limestones deposited at

181 upper-middle bathyal depths in the Aturian Trough during the late Maastrichtian to

182 Paleocene (Galbrun and Gardin, 2004; Alegret et al., 2004; Font et al., 2011). Deposition 
183 occurred in a flysch zone and accumulated at $3-4 \mathrm{~cm} / \mathrm{ky}$, resulting in thick marl beds

184 (Seyve, 1984; Nelson et al., 1991; Clauser, 1994; Peybernes et al., 1997; Vonhof and

185 Smit, 1997). Tectonic disturbance (Pyrenean orogeny) and diapirism resulted in interbed

186 sliding, slickensides, and mass-flow deposits (Razin, 1989; Apellaniz et al., 1997).

187 About $8 \mathrm{~m}$ of uppermost Maastrichtian (C29r) pink to purple marlstones and

188 marls with occasional turbidites and cut by local faults are exposed below the KTB at

189 Bidart and can be traced throughout the Basque basin (Fig. 2A; Apellaniz et al., 1997). At

190 the base of the section analyzed is a $25-\mathrm{cm}$ thick marlstone followed by $\sim 2.5 \mathrm{~m}$ of marls

191 with common pelecypod shells and fragments. In the $\sim 50-\mathrm{cm}$ below the KTB carbonate

192 content decreases and macrofossils are absent, except at the top of this interval where

193 burrows are truncated by the overlying boundary clay.

194 The KTB is easily recognized by a $2 \mathrm{~mm}$ "rusty" layer at the base of an $8-15 \mathrm{~cm}$

195 thick clay layer (Fig. 2B, C; Bonté et al., 1984; Apellaniz et al., 1997). The base of the

196 clayey interval is a grey to yellow silty clay overlain by red-brown siltstone and a thinly

197 laminated dark grey siltstone at the top. Carbonate content gradually increases in the

198 overlying basal Danian claystones, which are overlain by hemipelagic limestones marked

199 by alternating pink and white (occasionally glauconitic) biogenic limestones bioturbated

200 near the top of the section (Apellaniz et al., 1997; Font et al., 2011). At the top of the

201 outcrop is a mass-flow deposit with an erosive basal surface.

202

203 3.2. Gamsbach, Austria

204

205

The KTB boundary section is located in the Gamsbach valley of the Austrian

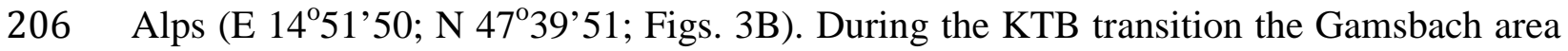


207 was located in the northwestern Tethys between paleolatitudes $20^{\circ}$ to $30^{\circ} \mathrm{N}$ (Fig. 1;

208 Haubold et al. 1999; Pueyo et al. 2007). The basin was formed after the early Cretaceous

209 thrusting followed by transtension and subsidence due to subduction (Wagreich, 1993,

210 1995). Erosion at the front of the Austro-Alpine microplate resulted in deposition of

211 sediments at middle bathyal depths (600-1000 m) during the late Maastrichtian and lower

212 bathyal depth (>1000 m) in the early Danian (Egger et al., 2009).

213 Sediments consist of hemipelagic pelites interbedded with thin sandy turbidites

$214(<15 \mathrm{~cm})$ characteristic of the Nierental Formation of the Gosau group in the northern

215 calcareous Alps (Wagreich and Krenmayr, 1993, 2005). The Maastrichtian is composed

216 of medium gray marlstones and marly limestones. Truncated burrows mark the top of the

217 Maastrichtian below the 2-cm thick clay layer that marks the KT boundary. This KT clay

218 layer contains $0.2-0.4 \mathrm{~cm}$ thick yellowish clay at the base (Fig. 3A, C).

\section{MATERIAL AND METHODS}

Sampling at Bidart concentrated on the $3.5 \mathrm{~m}$ interval below the KTB with 223 samples collected at $15-\mathrm{cm}$ intervals for the bottom $3 \mathrm{~m}$ and $5-\mathrm{cm}$ intervals for the top 50

$224-\mathrm{cm}$. At Gamsbach, $2 \mathrm{~m}$ of the uppermost Maastrichtian below the KTB were sampled at $2255-6 \mathrm{~cm}$ intervals. In the laboratory, samples were crushed into small fragments and left 226 overnight in $3 \%$ hydrogen peroxide solution to oxidize any organic carbon. The 227 disaggregated sediment samples were then washed through $>63 \mu \mathrm{m}$ and $>38 \mu \mathrm{m}$ sieves

228 (Keller et al., 1995). The washed residues were oven dried at $50^{\circ} \mathrm{C}$. Quantitative faunal 229 analysis was based on $63-150 \mu \mathrm{m}$ and $>150 \mu \mathrm{m}$ size fractions. Each size fraction of every 
230 sample was split with an Otto micro-splitter to obtain approximately 300 specimens of

231 planktic foraminifera (for a statistical representation of the species population). These

232 were picked, sorted and mounted on micro-slides and identified. The residual sample was

233 searched for rare species and index species for biostratigraphy but not included in the

234 quantitative dataset. Species identification is based on standard taxonomic concepts (e.g.,

235 Robaszynski et al., 1983-1984; Nederbragt, 1991; Olsson et al., 1999).

236 For the foraminifera fragmentation index, a microsplitter was used to obtain

237 approximately 500-700 foraminifera and fragments from the $>63 \mathrm{~mm}$ fraction such that at

238 least 100 entire tests were counted. Three categories were identified based on the quality

239 of preservation: entire (nearly) perfect tests (Plate 1, Plate 3: A-G), partially damaged

240 (imperfect) tests (Plate 2: A-L; Plate 3: H-L, O, P) and fragments (Plate 2: M-T; Plate 3:

241 M, N, Q-S). Specimens consisting of less than two-third of an entire test were counted as

242 fragments (Berger et al., 1982). Planktic foraminifera fragmentation data was obtained

243 for Bidart, Gamsbach and Elles sections. Benthic foraminifera fragmentation data was

244 also obtained for Bidart to account for mechanical breakage due to post-depositional

245 transport and sample processing techniques.

246 Stable carbon and oxygen isotope analyses were performed on whole-rock

247 samples from Gamsbach for this study. These analyses were conducted using a Thermo

248 Fisher GasBench II preparation device interface with a Thermo Fisher Delta Plus XL

249 continuous flow isotope ratio mass spectrometer at the Institute of Earth Surface

250 Dynamics (IDYST) of the University of Lausanne, Switzerland. The stable carbon and

251 oxygen isotope ratios are reported in delta $(\delta)$ notation as permil $(\% \circ)$ deviation relative to

252 the Vienna Pee Dee belemnite (VPDB). Whole rock and clay mineral data were acquired 
253 from XRD analyses using SCINTAG XRD 2000 Diffractometer at the Geological

254 Institute of the University of Lausanne, Switzerland. The procedure for sample

255 processing was based on Adatte et al. (1996).

256 Mass specific magnetic susceptibility (MS) was measured at the Institute Dom

257 Luís (IDL), at the University of Lisbon, Portugal with a MFK-1 (AGICO). Rock

258 fragments were crushed by using an agate mortar and filled within typical cubic plastic

259 boxes of $8 \mathrm{~cm}^{3}$ in volume. MS values are reported relative to mass $\left(\mathrm{m}^{3} / \mathrm{kg}\right)$.

261 5. BIOSTRATIGRAPHY: HOW COMPLETE IS THE KTB TRANSITION?

263 To evaluate the stratigraphic completeness of the KTB transition we apply the 264 high-resolution planktic foraminiferal zonal scheme by Li and Keller (1998a,b) and 265 Keller et al. (1995, 2002a) (Fig. 4). The KTB is placed at 65.5 Ma (Gradstein et al., 266 2004). However, the precise age of this boundary event is in flux with more recent 267 geochronologic dating suggesting an age closer to 66.0 Ma (Renne et al., 2013) and 268 additional dating still in progress. Based on cyclostratigraphy the duration for 269 paleomagnetic chron $\mathrm{C} 29 \mathrm{r}$ is estimated at $750 \mathrm{ky}$ with the base of $\mathrm{C} 29 \mathrm{r}$ at $66.25 \mathrm{Ma}$ 270 (Gradstein et al., 2004; Schoene et al., 2014; Thibault et al., this vol.).

271 Uppermost Maastrichtian Zone CF1: This zone is defined by the total range of 272 the index species $P$. hantkeninoides. Previous studies concluded that $P$. hantkeninoides is 273 absent at Bidart (Arz and Molina, 2002; Gallala et al., 2009; Galalla, 2013). However, we 274 observed this species in the $5 \mathrm{~m}$ below the KTB (see also Font et al., 2014) and $1.75 \mathrm{~m}$ 275 below the KTB at Gamsbach (Supplementary material Section 3). This indicates that in 
276 both localities the uppermost Maastrichtian zone CF1 is present. Zones CF1 and CF2 are

277 equivalent to the upper part of the nannofossil M. prinsii zone, which spans the top $8 \mathrm{~m}$

278 of the Bidart section (Galbrun and Gardin, 2004) and corresponds to C29r below the

$279 \mathrm{KTB}$. The sediment accumulation rate for this interval is $3.2 \mathrm{~cm} / \mathrm{ky}(800 \mathrm{~cm} / 250 \mathrm{ky})$ and

$2803.1 \mathrm{~cm} / \mathrm{ky}$ for zone CF1. Previous studies estimated a sedimentation rate of $4 \mathrm{~cm} / \mathrm{ky}$ for

281 the Maastrichtian distal sea fan at Bidart (Seyve 1990; Nelson et al., 1991; Vonhof and

282 Smit, 1997) and $2.5 \mathrm{~cm} / \mathrm{ky}$ for the nearby Sopelana section (Mary et al., 1991). This study

283 suggests that the zone CF1 interval is substantially complete, although truncated burrows

284 at the top of CF1 just below the KT boundary clay suggest some erosion. Compared with

285 the middle bathyal environment at Bidart, the middle shelf depositional environment at

286 Elles, Tunisia, reveals a much higher sediment accumulation rate of $8.6 \mathrm{~cm} / \mathrm{ky}$ for $\mathrm{C} 29 \mathrm{r}$

287 below the KTB. Based on this section, the duration of zone CF1 is estimated at $\sim 160 \mathrm{ky}$

288 based on the KTB at 65.5 Ma (Gradstein et al., 2004). Considering the KTB at $66 \mathrm{Ma}$ and

289 the $\mathrm{C} 30 \mathrm{n} / \mathrm{C} 29 \mathrm{r}$ transition at $\sim 66.288 \mathrm{Ma}$, zone $\mathrm{CF} 1$ at Elles is $\sim 130 \mathrm{ky}$ long (Renne et al.,

290 2013; Schoene et al., 2014)

291 At Gamsbach, P. hantkeninoides was identified in the top $\sim 1.75 \mathrm{~m}$ of the

292 Maastrichtian for the first time in this study (Fig. 6B, Plate 1: M). Truncated burrows

293 mark the top of zone CF1 below the boundary clay similar to Bidart. Based on these

294 observations we conclude that the upper part of zone CF1 to the KTB mass extinction at

295 Gamsbach is similar to Bidart and substantially complete. The abrupt negative $\delta^{13} \mathrm{C}$ shift

296 in bulk rock at the KTB and the presence of an erosional surface truncating burrows at

297 both Gamsbach and Bidart suggests some erosion. Biostratigraphy indicates that erosion 298 was primarily of basal Danian sediments. 
300 overlying the Maastrichtian mass extinction horizon. The boundary is easily identified on

301 the basis of five globally verified criteria: (1) mass extinction of Cretaceous planktic

302 foraminifera, (2) appearance of the first five Danian species within a few $\mathrm{cm}$ of the

303 boundary clay, (3) KTB clay and red layer, (4) an Ir anomaly and (5) the $\delta^{13} \mathrm{C}$ negative

304 shift (Keller et al., 1995; 2011b). The KTB is also characterized by an abrupt increase in

305 magnetic susceptibility (Font et al., 2011; this study). At Bidart and Gamsbach, the KTB

306 clay is very thin ( $\sim 5 \mathrm{~cm}$ and $\sim 3 \mathrm{~cm}$ respectively) and overlies an erosion surface with

307 truncated burrows. The zone P0 clay, which is defined by the interval between the mass

308 extinction horizon and first appearance of Parvularugoglobigerina eugubina, is absent as

309 this species directly overlies the mass extinction horizon. Ir anomalies of $6.3 \mathrm{ppb}$ and

$310 \sim 6.0 \mathrm{ppb}$ at Bidart and Gamsbach, respectively (Bonté et al., 1984; Vonhof and Smit,

311 1997; Egger et al., 2009) are concentrated in the thin clay that represents redox conditions

312 above the erosion surface. Similarly, the $\delta^{13} \mathrm{C}$ negative shift of 2.0 to $2.3 \%$ is abrupt

313 across the erosion surface in both sections (Rocchia et al., 1987; Font et al., 2014). In

314 comparison, at the stratotype El Kef and expanded Elles sections in Tunisia, the P0 clay

315 is 50 to $75 \mathrm{~cm}$ thick with an Ir anomaly of $18 \mathrm{ppb}$ at the base and a $4 \%$ negative carbon

316 isotope excursion (Rocchia et al., 1996; Stuben et al., 2003). The relative time

317 represented by the condensed P0 intervals and hiatuses at Bidart and Gamsbach can be 318 estimated based on the zone P1a planktic foraminiferal assemblages.

319 Zone P1a hiatuses: This zone is defined by the total range of $P$. eugubina and/or

$320 P$. longiapertura and can be subdivided into subzones $\mathrm{P} 1 \mathrm{a}(1)$ and $\mathrm{P} 1 \mathrm{a}(2)$ based on the $\mathrm{FO}$

321 of Parasubbotina pseudobulloides and/or Subbotina triloculinoides (Fig. 4). At the time 
322 of the P0/P1a(1) boundary only about five early Danian species had evolved and all were

323 rare as the assemblages were dominated by the Cretaceous survivor and disaster

324 opportunists Guembelitria species (review in Keller and Pardo, 2004).

325 At Bidart, zone P1a(1) directly overlies the mass extinction with common

326 Parvularugoglobigerina extensa, $P$. eugubina and $P$. longiapertura, an assemblage that is

327 known to first appear well into zone P1a(1) about 100 kyr after the KTB mass extinction

328 (Fig. 5A). This indicates that the early evolution of Danian species in P0 and lower part

329 of P1a(1) is missing due to erosion or non-deposition (Fig. 4). About 30-cm above this

330 hiatus subzone P1a(1) ends with another sudden faunal assemblage change marked by

331 dramatically decreased Guembelitria, P. eugubina and $P$. longiapertura, a sudden

332 appearance of abundant Chiloguembelina morsei and the FO of S. triloculinoides (Fig.

333 5A). This assemblage is indicative of subzone $\mathrm{P} 1 \mathrm{a}(2)$ and marks another short hiatus

334 between subzones P1a(1) and P1a(2) (Fig. 4). Hiatuses at the KTB and lower Danian

335 (resulting from condensed sedimentation and/or deep-sea currents) have been

336 documented worldwide in various studies (reviews in MacLeod and Keller, 1991; Keller

337 et al., 2003, 2013).

338 At Gamsbach an early Danian hiatus is also present as evident by the diverse (12

339 species) early Danian assemblage including P. pseudobulloides, the index species for

340 subzone $\mathrm{P} 1 \mathrm{a}(2)$ directly overlying the mass extinction horizon (Fig. 6A). This indicates

341 erosion of $\mathrm{P} 0, \mathrm{P} 1 \mathrm{a}(1)$ and at least part of $\mathrm{P} 1 \mathrm{a}(2)$ (Fig. 4). Another abrupt faunal change

342 and hiatus occurs at the $\mathrm{P} 1 \mathrm{a}(2) / \mathrm{P} 1 \mathrm{~b}$ boundary about 30-cm above the KTB marked by the

343 extinction of $P$. eugubina and $P$. longiapertura (index for top $\mathrm{P} 1 \mathrm{a}(2)$ ) and terminal

344 abundance decrease in Globigerina edita. Above this hiatus abundant C. morsei and 
345 common P. pseudobulloides followed by abundant Guembelitria spp. indicates zone P1b

346 (Figs. 4, 6A).

348 6. STABLE ISOTPES AND FAUAL TURNOVER

350 6.1. Stable isotopes

351 Whole-rock stable carbon and oxygen isotope data for Gamsbach (Austria) were 352 obtained for this study (supplementary materials Table 7). Planktic, benthic and bulk

353 stable isotope data for Elles (Tunisia) and whole-rock isotope data for Bidart (France)

354 have already been documented (Stüben et al., 2003; Thibault et al., this vol.; Font et al.,

355 2014). Visual inspection of preservation and degree of recrystallization of individual

356 foraminifera tests indicated that the Gamsbach isotope data were likely to be the most 357 compromised.

358 At Elles, the overall low $\delta^{18} \mathrm{O}$ values $(-7.0$ to $-4.0 \%$ ) for planktic as well as

359 benthic (-4.5 to $-2.0 \%$ ) foraminifera indicate diagenetic effects but long term trends may

360 still be preserved (Stüben et al., 2003; supplementary materials Table 5). At Bidart, the

361 whole-rock $\delta^{13} \mathrm{C}$ values range between -1.7 and $1.8 \%$ and bulk $\delta^{18} \mathrm{O}$ values range

362 between -3.2 and $-0.3 \%$. Plotting $\delta^{13} \mathrm{C}$ vs. $\delta^{18} \mathrm{O}$ values yields a correlation coefficient

$363 \mathrm{R}^{2}=0.53$, suggesting that diagenetic alteration of the primary signal may not be ruled out

364 (supplementary materials Table 6). A low $\delta^{13} \mathrm{C}$ event is recognized between $3.5 \mathrm{~m}$ and

$3650.75 \mathrm{~m}$ below the KTB. A similar event is also observed in the planktic $\delta^{13} \mathrm{C}$ values at

366 Elles between $1.75 \mathrm{~m}$ and $6.6 \mathrm{~m}$ below the KTB boundary indicating that this signal may

367 be real (Fig. 7). A long term increasing trend through zone CF1 is observed in $\delta^{18} \mathrm{O}$ 
368 profiles of Bidart, Gamsbach and Elles, although the values at Gamsbach and Elles

369 record frequent fluctuations (Fig. 8). The whole-rock $\delta^{13} \mathrm{C}$ values for Gamsbach range

370 between 1.41 to $2.42 \%$ and the bulk $\delta^{18} \mathrm{O}$ range between -2.6 and $-1.1 \%$ o. The $\delta^{13} \mathrm{C}$ vs.

$371 \delta^{18} \mathrm{O}$ correlation coefficient is lower than that for Bidart $\left(\mathrm{R}^{2}=0.27\right)$ but the poorly

372 preserved fragmented and recrystallized tests suggest considerable overprint on the

373 primary isotopic composition. The low $\delta^{13} \mathrm{C}$ event of Bidart and Elles is not preserved at

374 Gamsbach.

375

376 6.2. Faunal Turnover

377 Bidart (France)

378 Maastrichtian planktic foraminifera at Bidart are recrystallized but relatively well

379 preserved and identification is fairly easy. About 51 species were identified in the $63-150$

$380 \mu \mathrm{m}$ size fraction and 23 species in the $>150 \mu \mathrm{m}$ size fraction (Fig. 5A). The species

381 richness in the $63-150 \mu \mathrm{m}$ fraction gradually drops from 30 to 20 through the analyzed

382 interval of zone CF1. A rapid decline from $\sim 20$ species to 3 species is seen $3-\mathrm{cm}$ below

383 the KTB. A brief increase to 13 species occurs $2-\mathrm{cm}$ above the boundary clay is observed

384 in the small and large size fractions and is likely due to erosion and redeposition (Fig.

$3855 \mathrm{~A})$. In the $>150 \mu \mathrm{m}$ fraction, diversity remains nearly constant through CF1 but declines

386 from $\sim 50$ species to 11 species at 3 -cm below the KTB.

387 All typical late Maastrichtian globotruncanids, rugoglobigerinids, heterohelicids

388 and pseudoguembelinids are represented, although the biserial heterohelicids and

389 pseudoguembelinids dominate the assemblages in the 63-150 um (Fig. 5B). In addition to

390 common cosmopolitan species, biserial species Hartella harti and Spiroplecta americana 
391 Ehrenberg are also frequent in the assemblage (Plate 1: K, J); these species were first

392 described by Georgescu and Abramovich (2009) from upper Maastrichtian sediments of

393 the Atlantic Ocean. At Bidart $H$. harti and Heterohelix navarroensis are the most

394 abundant and together constitute $40-60 \%$ of the assemblage throughout CF1 (Figs. 5B, 7;

395 Plate 1: K, L). Guembelitria sp. is present in the $63-150 \mu \mathrm{m}$ size fraction but not in the

396 abundance observed in shallow marine KTB transitions (e.g. Egypt, Sinai, Tunisia

397 (Seldja); Keller and Benjamini, 1991; Keller et al., 1997; Keller, 1998b; 2002b; Punekar

398 et al., 2014b; Plate 1: I). The newly evolved Danian assemblage in zone P1a(1) is

399 dominated by Guembelitria sp. and Parvularugoglobigerina sp. (30-40\%, Fig. 5A). The

$400 \mathrm{P} 1 \mathrm{a}(2)$ assemblage is dominated by Chiloguembelina midwayensis. (See supplementary

401 material Fig. S1 for planktic foraminifera in the $>150 \mu \mathrm{m}$ size fraction at Bidart)

402 Gamsbach (Austria)

403 A planktic foraminiferal study by Korchagin in Grachev et al. (2005) identified

404 only 25 Maastrichtian species and placed this assemblage in the Abathomphalus

405 mayaroensis zone, which spans most of the late Maastrichtian $(68.72-65.5 \mathrm{Ma})$. The

406 preservation of Maastrichtian planktic foraminifera in the $63-150 \mu \mathrm{m}$ fraction at

407 Gamsbach is very poor. Recrystallization and the difficulty of freeing specimens from

408 surrounding sediments result in specimens with a highly fragmented and abraded

409 appearance and no reliable quantitative data can be obtained for the Maastrichtian

410 (supplementary material Fig. S2). In the $>150 \mu \mathrm{m}$ fraction preservation is better and

411 therefore was analyzed quantitatively (Fig. 6B). A total of 46 species were identified in

412 the $>63 \mu \mathrm{m}$ size fraction which is likely an underestimate of the total assemblage due to

413 poor preservation. Most species are consistently present in the lower $1.25 \mathrm{~m}$ of the 
414 section. But in the uppermost $0.5 \mathrm{~m}$, species are more sporadic and species richness drops

415 from 46 to $21-30$ species. In the $>150 \mu \mathrm{m}$ fraction, species richness ranges between $30-40$

416 species and drops from $\sim 25$ to 8 species at the KTB (Fig. 6A).

417 All common Maastrichtian groups such as the globotruncanids, rugoglobigerinids,

418 heterohelicids and pseudoguembelinids are present in the assemblage. Pseudotextularia

419 elegans, Pseudotextularia nuttali, Pseudoguembelina hariaensis, Heterohelix globulosa

420 and Planoglobulina brazoensis dominate the $>150 \mu \mathrm{m}$ fraction (Fig. 6B). Guembelitria

421 sp. is almost absent in the $63-150 \mu \mathrm{m}$ fraction. In contrast to Bidart, $H$. harti and $S$.

422 americana are not present in the assemblage (Fig. 8C). In the Danian, the diversity in

423 zone $\mathrm{P} 1 \mathrm{a}(2)$ is about 10 species which increases to 20 species in zone P1c. The $\mathrm{P} 1 \mathrm{a}(2)$

424 assemblage overlying the KTB is dominated by $G$. cretacea, $P$. eugubina, $P$.

425 longiapertura, Globigerina edita, Globanomalina archaeocompressa and Praemurica 426 taurica (Fig. 6A).

427

428 6.3. Depth-ranked species

429 Planktic foraminifera species have been classified into surface dwelling 430 opportunistic species Guembelitria, surface-subsurface mixed layer, intermediate or

431 thermocline and deep-water dwellers based on stable oxygen and carbon isotope ranking

432 of well-preserved specimens (Abramovich et al., 2003, 2010). The diversity and

433 abundance changes for each depth group can indicate climatic and environmental effects

434 at different depths of the water column. Figure 9 shows the diversity and abundance of

435 the four groups in small $(63-150 \mu \mathrm{m})$ and larger $(>150 \mu \mathrm{m})$ size fractions analyzed

436 through zone $\mathrm{CF} 1$ at Bidart and Gamsbach and compared with Elles, Tunisia 
437 (Supplementary material Section 5, Table 1 show the depth-ranked grouping of species 438 used for this study).

439 At Bidart, the small sized opportunistic Guembelitria (63-150 $\mu \mathrm{m}$ fraction) are

440 rare in the lower part of the section and slightly increase in the upper $\sim 1.5 \mathrm{~m}$ below the

441 KTB (Fig. 9B). This group is not as rare in Elles but the relative abundance is $<10 \%$ (Fig.

442 9A). The subsurface mixed layer dwellers (Table 1) constitute $80-90 \%$ of the CF1

443 assemblage at both Bidart and Elles. In the small size fraction, this group at Bidart with

$44430-40$ species is almost twice as diverse as at Elles, (10-20 species). In the $>150 \mu \mathrm{m}$

445 fraction, the relative abundance of mixed layer dwellers constitute $60-80 \%$ at Bidart and

$446 \sim 80 \%$ at Elles (Fig. 9A, B). Their diversity fluctuates through CF1 and shows a gradual

447 decrease from $\sim 20$ to 14 species followed by a rapid decline $\sim 3 \mathrm{~cm}$ below the KTB. The

448 thermocline dwelling globotruncanids are rare in the small size fraction at both Bidart

449 and Elles with relative abundance $<5 \%$. Two peaks of increased abundance and diversity

450 are noted in the upper 30-cm of late Maastrichtian at Bidart and in the last meter at Elles.

451 In the $>150 \mu \mathrm{m}$ fraction, thermocline dwellers are more abundant (20-30\%) at Bidart

452 compared to the same group in Elles $(<10 \%)$. The sub-thermocline deep-water dwellers

453 in both size fractions at Bidart and Elles show consistently low abundances $(<5 \%)$ and

454 diversity (<3 species) throughout zone CF1 (Fig. 9A, B).

455 At Gamsbach the mixed dwellers dominate in the larger size fraction, with $\sim 70 \%$

456 relative abundance, followed by the thermocline dwellers with $25-30 \%$ abundance. The

457 high abundance of thermocline dwelling globotruncanids in Gamsbach is more 458 comparable to the assemblage at Bidart than that at Elles (Fig. 9C). The deep dwellers are 459 represented by $1-3$ species and account for $<10 \%$ throughout CF1. 
461 to be related to deposition in a relatively shallow continental shelf vs. deep middle

462 bathyal environments. This is indicated by the similarity in the faunal compositions

463 between Bidart, Gamsbach and the middle bathyal DSDP Site 525A, but dissimilarity

464 with Elles. For example (1) there is significantly higher relative abundance of $P$.

465 hariaensis at Bidart (20-25\%), Gamsbach (10-20\%) and Site 525A (10-20\%), compared

466 with Elles (<5\%) Abramovich and Keller, 2002; 2003); (2) Heterohelix globulosa is less

467 abundant in the $>150 \mu \mathrm{m}$ fraction at Bidart (15-20\%), Gamsbach ( $<10 \%$ with acme of

$46820 \%$ ) than at Elles (40-50\%); (3) Planoglobulina brazoensis is more abundant (5-10\%) in

469 all three deeper sections, but rare at Elles; and (4) Globotruncana arca is more abundant

470 at Bidart (10\%), Gamsbach (10-20\%) and Site 525A (20-30\%) than at Elles $(<5 \%)$.

471

472

473

474

\section{$475 \quad 7.1$ Magnetic Susceptibility (MS)}

476

477 mineralogical composition, and includes contributions (in proportion to their abundance)

478 from all - diamagnetic (e.g., calcite), paramagnetic (e.g., clay) and ferromagnetic (ex:

479 magnetite) - minerals present in the sediment. Since the pristine signal of magnetic

480 susceptibility in marine sediment reflects the balance between detrital input (high MS)

481 and carbonate productivity (low MS), it represents a robust paleoenvironmental indicator.

482 The rock magnetic properties for Elles are published in Stüben et al. (2003) and for

483 Bidart in Font et al. (2011, 2014) and Font and Abrajevitch (2014). 
485 are in the range of $10^{-7}$ to $10^{-6} \mathrm{~m}^{3} / \mathrm{kg}$, and comparable to other marine sediments

486 worldwide (Ellwood et al., 2008). The overall MS profile for zones CF3-CF1 shows a

487 positive correlation with percent phyllosilicates and an inverse correlation with carbonate

488 content, indicating a strong relationship between MS, climate (precipitation and runoff)

489 and/or sea-level rise. The KTB is featured by an abrupt shift in MS values, probably

490 resulting from an abrupt change in lithofacies (i.e. the clay layer). The Elles section does

491 not show the typical low MS interval below the KT boundary as in Bidart (Fig. 10A). At

492 Bidart the average MS value is $1.85 \times 10^{-7} \mathrm{~m}^{3} / \mathrm{kg}$ for the lower part of zone CF1 and

$493 \sim 0.84 \times 10^{-7} \mathrm{~m}^{3} / \mathrm{kg}$ for the final $\sim 60 \mathrm{~cm}$ that forms the benchmark interval. The

494 characteristic abrupt increase in MS values (to $4.62 \times 10^{-7} \mathrm{~m}^{3} / \mathrm{kg}$, likely due to or a very

495 rapid change in sedimentation) marks the KTB hiatus at Bidart (Fig. 10B). For the

496 Gambsach section, the mass specific magnetic susceptibility of 49 samples excluding

497 turbiditic levels was measured (Fig. 10C). Maastrichtian MS values range between $10^{-8}$ to

$49810^{-7} \mathrm{~m}^{3} / \mathrm{kg}$. The average MS value for the lower part of zone CF1 is $6.7 \times 10^{-8} \mathrm{~m}^{3} / \mathrm{kg}$. About

$499 \sim 60 \mathrm{~cm}$ below the KTB, MS values reach a minimum of $4.5 \times 10^{-8} \mathrm{~m}^{3} / \mathrm{kg}$ (average of

$5005.1 \times 10^{-8} \mathrm{~m}^{3} / \mathrm{kg}$ ). These low MS values persist over an interval of $36-\mathrm{cm}$. Across the KTB

501 MS values show the typical increase culminating at $2.3 \times 10^{-7} \mathrm{~m}^{3} / \mathrm{kg}$, similar to Bidart and

502 other KTB sections (e.g., Gubbio, Oman: Ellwood et al., 2003; Atlantic ODP 1259:

503 Erbacher et al., 2004; North Atlantic ODP 1049A: Moore et al., 1998).

504

505 7.2. Percent calcium carbonate 
506 Whole-rock percent $\mathrm{CaCO}_{3}$ content of marine sediments is the net result of the

507 local paleaoclimate, calcareous nannoplankton and calcareous dinoflagellate

508 palaeoproductivity, planktic foraminiferal abundance, water column $\mathrm{pH} /$ dissolution, pore-

509 water dissolution/re-crystallization and detrital influx. For localities with greater

510 terrigenous influx the ratio of $\mathrm{Ca} /$ detritus is a better estimate of biogenic $\mathrm{CaCO}_{3}$ as it

511 accounts for the detrital contribution. At Elles, the calcite/detritus ratio is low (0.5) near

512 the base of zone CF1 (8-10 m below the KTB, Fig. 10A). In this interval, the

513 phyllosilicate content is relatively high (25-35\%) with an increasing trend. The

$514 \mathrm{Ca}$ /detritus ratio fluctuates but increases to $0.75-1.00$ about 5-8 $\mathrm{m}$ below the KTB along

515 with an increase in MS values. The Ca/detritus ratio is higher in the top $4 \mathrm{~m}$ of zone $\mathrm{CF} 1$,

516 albeit with three sharp decreases.

517 The percent $\mathrm{CaCO}_{3}$ at Bidart gradually decreases from $55 \%$ at the base of zone

518 CF1 to about $40 \% 2 \mathrm{~m}$ below the KTB. An increase to $50 \%$ is observed $1.5 \mathrm{~m}$ below

519 KTB followed by values between $40-50 \%$ up to the low MS interval where values

520 sharply increase to $60 \%$ about $0.25 \mathrm{~m}$ below the KTB (Fig. 10B). At Gamsbach, $\mathrm{CaCO}_{3}$

521 ranges between $40-50 \%$ and records several abrupt decreases in zone CF1 correlative

522 with abrupt changes in percent quartz and MS values (Fig. 10C). In the $1 \mathrm{~m}$ below the

$523 \mathrm{KTB} \mathrm{CaCO}_{3}$ varies between $55-80 \%$ with the largest drop $\sim 20 \mathrm{~cm}$ below the KTB

524 correlative with increased phyllosilicates and MS values. A drop in $\mathrm{CaCO}_{3}$ to nearly zero

525 percent is indicated in the KTB clay in all three sections.

526

$527 \quad 7.3$ Fragmentation index 
529 to a multitude of taphonomic processes. Acidic ambient waters react with planktic

530 foraminiferal test carbonate, which leads to test dissolution and enhanced fragmentation.

531 The number of fragments have been used as a quantitative estimate of low $\mathrm{pH}$ in 532 foraminiferal assemblages (Thunell, 1976; Berger et al., 1982). The fragmentation index

533 may be calculated based on the following equation (Williams et al., 1985; Malmgren, 534 1987):

535

536

537

538

539

540 fragments, the equation requires the total number of counted fragments to be divided by 8

541 to estimate the original number of whole tests. This is because the number of fragmented

542 tests is a better approximation of dissolution effects than the total number of fragments

543 counted (Le and Shackleton, 1992). As most of the planktic foraminifera at Bidart, Elles

544 and Gamsbach are recrystallized and/or infilled with secondary calcite, they are relatively

545 more resistant to fragmentation than pristine tests. We adjust for recrystallization by

546 reducing the number of fragments per test to 6 instead of 8 to avoid underestimation of

547 fragmented tests. Similarly, we consider 2 fragments per test for benthic foraminifera for

548 Bidart as they are far more resistant to fragmentation.

549 The stacked area graphs of Fig. 10 show fragmentation indices for Elles, Bidart

550 and Gamsbach. At Elles, fragmented tests increase from 23\% to $46 \%$ at the beginning of

551 the low MS interval and increased fragmentation and imperfect tests are observed in the

552 top $4 \mathrm{~m}$ below the KTB (Fig. 10A). At Bidart, the percentage of imperfect tests for the

553 lower part of CF1 is considerably higher than at Elles and that of fragmented tests is 
554 lower (Fig. $10 \mathrm{~A}-\mathrm{B}$ ). In the uppermost $\sim 60 \mathrm{~cm}$ of zone $\mathrm{CF} 1$, the low-MS interval is

555 accompanied by a significant $(p<0.0001)$ increase in the combined abundance of

556 imperfect and fragmented from $\sim 25 \%$ to $70 \%$ ( $\sim 0.3 \mathrm{~m}$ below KTB, Fig. 10B). A drop in

557 this percentage $\sim 2.5 \mathrm{~m}$ below the KTB boundary is followed by a rapid increase to $90 \%$.

558 It must be noted that the fragmented tests (not the imperfect tests) dominate at the KTB

559 boundary hiatus. The fragmentation index at Gamsbach also shows an abrupt increase in

560 the combined abundance of fragmented and imperfect tests from $40 \%$ to $~ 90 \%$ at the

561 onset of the low MS interval $\sim 50 \mathrm{~cm}$ below the KTB boundary. Within this interval,

562 fragmentation continues to be high ( $90 \%)$ up to the KTB boundary (Fig. 10C). A brief

563 episode of decreased fragmentation is observed $\sim 20 \mathrm{~cm}$ below the KTB boundary similar

564 to the event recorded at Bidart (supplementary material Tables 2-4). Figure 11 compares

565 the fragmentation indices of planktic and calcareous benthic foraminifera at Bidart. The

566 proportion of fragments of benthic foraminifera remains $2-3 \%$ for most of the analyzed

567 CF1 interval (Plate 3: M, N, Q-S). This is consistent with the general robustness of

568 benthic morphologies and likely indicates a limited/uniform influence of sample

569 processing techniques and post-depositional breakage on the assemblage. However, an

570 increase in the fragments to $\sim 5 \%$ concurrent with the Deccan benchmark event may

571 imply enhanced post-depositional bottom water transport during the climate-cooling

572 event (Figs. 10, 11). The imperfect benthic tests of CF1 largely show mechanical damage

573 unlike the planktic counterparts that show chemically leached surfaces and holes (Plate 2:

574 A-L). However, at the KTB and the lowermost Danian, sediments contain benthic

575 foraminifera that show intense leaching as well as mechanical damage strongly indicating

576 a dominance of post-depositional dissolution and bottom water transport affecting the 
577 assemblage. The planktic FI is not useful to isolate water column dissolution effects in

578 these samples (Fig 11).

579

$580 \quad$ 7.4 Preferential preservation of robust morphologies

581 Dissolution preferentially decreases the relative abundance of thin-walled test

582 morphologies and therefore increases the relative abundance of robust dissolution-

583 resistant tests (e.g. Globotruncana, Globotruncanita, Pseudotextularia and $P$.

584 brazoensis), which may explain the increased calcite at this interval. This bias is evident

585 just below the KTB mass extinction in all three profiles analyzed. In the middle shelf

586 environment of Elles, globotruncanids and pseudotextularids are rare in zone CF1 ( 1\%),

587 increase to $2 \%$ in the low-MS interval and peaks at $10 \%$ and $6 \%$ in the $1 \mathrm{~m}$ preceding the

588 mass extinction (Fig. 10A). In the middle bathyal sections of Bidart and Gamsach, the

589 abundance of globotruncanids average 20-30\% throughout zone CF1. At Bidart

590 globotruncanids abruptly reach $70 \%$ correlative with increased fragmentation and

591 decreased percent $\mathrm{CaCO}_{3}$ beginning about 30-cm below the KTB (Fig. 10B). At

592 Gamsbach, globotruncanids and another robust species (Planoglobulina brazoensis show

593 anomalously high abundance throughout zone CF1 with peak abundance of P. brazoensis

594 correlative with the high fragmentation index $\sim 15 \mathrm{~cm}$ below the KTB (Fig. 10C).

595

596 8. DISCUSSION

597

$598 \quad 8.1$ Paleoclimate 
600 calcareous nannoplankton) values in the deep-water sediments at Bidart and Gamsbach.

601 Diagenesis and recrystallization of tests may have overprinted $\delta^{18} \mathrm{O}$ signals but their

602 effects on the $\delta^{13} \mathrm{C}$ trend are limited. This claim is supported by the low correlation

603 coefficients of $\delta^{13} \mathrm{C}$ vs. $\delta^{18} \mathrm{O}$ (Stüben et al., 2003; $\mathrm{R}^{2}=0.53$ for Bidart and $\mathrm{R}^{2}=0.27$ for

604 Gamsbach) and the low correlation coefficient of $\delta^{13} \mathrm{C} v / \mathrm{s} \% \mathrm{CaCO}_{3}\left(\mathrm{R}^{2}=0.40\right.$ for Bidart 605 and $\mathrm{R}^{2}=0.39$ for Gamsbach).

606 The lower $\sim 3 \mathrm{~m}$ of zone CF1 at Bidart and lower $\sim 1.2 \mathrm{~m}$ of Gamsbach record 607 faunal responses comparable with those observed in the upper part of the late 608 Maastrichtian global warming at Elles and DSDP Site 525A. Globally, this warm event 609 began in zone CF2 as a likely consequence of the onset of the main phase-2 of Deccan 610 volcanism (Punekar et al., 2014a). This is consistent with the more negative $\delta^{18} \mathrm{O}$ values

611 for these intervals indicating higher temperatures (-2\%o for Bidart and -1.5 to $-2 \%$ o for

612 Gamsbach, Fig. 8). At Bidart, the late Maastrichtian warm event is associated with 613 changes in the relative abundance of heterohelicids (particularly $H$. planata, $H$.

614 navarroensis and $H$. globulosa) and increased $P$. hariaensis abundance in the $>150 \mu \mathrm{m}$ 615 fraction.

616 The end of the late Maastrichtian warming at Elles is marked by abrupt cooling 617 concurrent with unprecedented low MS values and increased test fragmentation $\sim 4 \mathrm{~m}$ 618 below the KTB. This could be an expression of increased volcanic $\mathrm{SO}_{2}$ emission and 619 acidification (Fig. 10 this study; Fig. 5 of Stüben et al., 2003). At Bidart the onset of this 620 same cooling event is recognized by a drop in MS associated with increased dissolution 
621 and disappearance of Globigerinelloides yaucoensis, P. costulata, G. subcarinatus and $R$.

622 rugosa and at Gamsbach the disappearance of G. subcarinatus (Figs. 8, 10).

623

$624 \quad$ 8.2 Paleoproductivity

625 Low $\delta^{13} \mathrm{C}$ values with multiple negative excursions are observed at Elles and

626 Bidart ( $\sim .5 \%$ and $\sim 0.7 \%$ o respectively) near the end of the late Maastrichtian CF1 warm

627 event Fig. 7). Similar negative excursions ( 1\%o) are recorded at deep marine Site 525A

$628(\sim 0.3 \%$ ) as well as in shallow marine environments of Texas and India (Meghalaya) (Li

629 and Keller, 1998a; Gertsch et al., 2011; Abramovich et al., 2011). The existing dataset

630 shows a greater magnitude of $\delta^{13} \mathrm{C}$ negative shift in the shallow sites (e.g., Meghalaya

631 (India), Mullinax-1 (Texas) and slightly deeper Elles (Tunisia). The smaller $\delta^{13} \mathrm{C}$ shift at

632 deeper Site 525A may be due to an incomplete record resulting from erosion of early

633 Danian and topmost Maastrichtian sediments ( $\mathrm{Li}$ and Keller, 1998a).

634 A rise in sea level near the end of the Maastrichtian and across the KTB transition

635 accompanied by increased precipitation and continental weathering/erosion (Haq et al.,

636 1988; Li et al., 1999) may have been responsible for the increased delivery of organic

637 carbon with very low $\delta^{13} \mathrm{C}$ values into shallow marine environments. Low primary

638 productivity could have been the other important contributor to the low $\delta^{13} \mathrm{C}$ values. Low

639 nannofossil productivity is recorded in Elles, Bidart, DSDP Site 525A, DSDP Site 577A

640 and DSDP Site 216 during the late Maastrichtian warm event in CF1 (Gorostidi and

641 Lamolda, 1995; Gardin, 2002; Tantawy et al., 2009; Thibault and Gardin, 2007, 2010).

642 Heterotrophic planktic foraminifera may have in turn suffered, resulting in a decrease in

643 carbonate export and the eventual $\delta^{13} \mathrm{C}$ value of bulk carbonate. The lower carbonate 
$644(40 \%)$ between 1.2-3.0 m below the KTB at Bidart, correlative with the low $\delta^{13} \mathrm{C}$ interval 645 lends support to this interpretation.

646 These global effects of increased precipitation and enhanced continental 647 weathering/erosion can be attributed to climate warming caused by ongoing large scale 648 Deccan volcanism. Additionally, the outgassing of higher-than-background quantities of 649 volcanic $\mathrm{CO}_{2}\left(\delta^{13} \mathrm{C}\right.$ about $-5 \%$ ) would also significantly contribute to lowering the $\delta^{13} \mathrm{C}$ 650 of the global oceans dissolved inorganic carbon (DIC), although the sediment record of 651 this signal would lag by $\sim 1000$ years (Zeebe, 2012).

652

\section{$653 \quad$ 8.3 Planktic Foraminifera}

654 The high abundance of planktic and near absence of benthic foraminifera at Bidart 655 is consistent with the high planktic:benthic ratio (>90\% planktics) reported by Coccioni 656 and Marsili (2007). The middle bathyal paleobathymetry and open marine setting appears 657 to be the reason for the unusual globotruncanid abundance at Bidart and Gamsbach (Fig. 658 9). This is supported by the high abundance of globotruncanids at Site $525 \mathrm{~A}(\sim 35-40 \%$, $659>150 \mu \mathrm{m}$ ) where deposition occurred at $1000 \mathrm{~m}$ depth (Shackleton and Boersma, 1985; 660 Abramovich and Keller, 2003). In relatively shallow $(<150 \mathrm{~m})$ continental shelf 661 environments, such as Elles, the diversity and abundance of globotruncanids is much 662 lower (Fig. 9).

663

\section{8.4 Pre-KTB Ocean Acidification}

665 White et al. (1994) showed that under present-day conditions ( $\mathrm{pH}$ rain=5.6), 666 magnetite grains have very long time residence $\left(>10^{7}\right.$ years $)$ on land, but can be rapidly 
667 dissolved under more acidic conditions. In marine sediments, iron oxide dissolution by 668 ocean acidification has previously been documented for the Triassic-Jurassic mass 669 extinction and the coeval Central Atlantic Magmatic Province (Abrajevitch et al., 2013), 670 and more recently in the case of the KTB mass extinction at Bidart and Gubbio (Font et 671 al., 2014). The top $\sim 50 \mathrm{~cm}$ interval of low-magnetic susceptibility (MS) that immediately 672 precedes the KTB at Bidart was attributed to the main phase-2 of Deccan volcanism 673 (Font et al., 2011, 2014; Font and Abrajevitch, 2014). The reductive iron oxide 674 dissolution may have occurred on land and/or in seawater. The first scenario was tested 675 by Font et al. (2014) who used a numerical weathering model to test for the consequences 676 of acidic rains on a continental regolith. Results revealed nearly complete magnetite 677 dissolution after $\sim 31 \mathrm{kyr}$ (with a $\mathrm{pH}$ of 3.3.). However, the dissolution of magnetotactic 678 bacteria, which generally thrive the oxic-anoxic boundary in deep-sea marine sediments, 679 evokes ocean acidification as well and requires validation (Font and Abrajevitch, 2014; 680 Abrajevitch et al., in review).

681 Factors affecting the nature and concentration of detrital magnetic minerals and 682 therefore the MS of sediments include the nature and proximity of continental sediment 683 sources carbonate productivity, sea-level changes and/or post-depositional alteration 684 mechanisms (oxidation due to weathering/ diagenetic reduction of oxides). The influence 685 of sea level change on bulk MS is based on the relative contribution of carbonate 686 (diamagnetic, low MS) versus detrital input (paramagnetic clays and ferromagnetic iron 687 oxides, high MS) and thus can be estimated by correlating MS data with phyllosilicates 688 where a direct positive correlation implies a strong dependence of both parameters.

689 At Elles, the pre-KTB low-MS interval is not evident probably because 
690 paramagnetic minerals (clays) dominate the MS signal, supported by very low Ca:detritus

691 ratios (Fig. 10). At Bidart, the correlation between percent phyllosilicates and MS in zone

$692 \mathrm{CF} 1$ is poor $(\mathrm{r}=0.088)$, indicating an overall weaker influence due to sea level changes or

693 turbidity currents. For Gamsbach, this correlation is more complicated due to the

694 presence of frequent turbidite beds that are rich in dia/paramagnetic-silicates (Fig. 10;

695 samples Gb 5, 10, 12, 15, 27-28). However, the MS profile of Gambsach does show low

696 MS values for the $\sim 40 \mathrm{~cm}$ interval below the KTB, similar to the MS profile of the Bidart

697 section (Fig. 10). The MS data of the present study thus suggest that the Gambsach

698 section is a good analog of the Bidart section. A prolonged period of acid rain on the

699 continents resulting in dissolution of magnetic detrital minerals can therefore be the

700 principal mechanism that caused the low MS intervals antecedent to the KTB because sea

701 level changes are a secondary influence on the MS profiles of Bidart and Gamsbach,

702 Surface ocean acidification in the low MS intervals of Bidart and Gamsbach is

703 indicated by increased dissolution and fragmentation of planktic foraminiferal tests (Fig.

704 10). This increased fragmentation interval correlates with the abrupt cooling event at

705 Elles ( 4 $\mathrm{m}$ to $\sim 0.5 \mathrm{~m}$ below the KTB), Bidart ( $\sim 0.5 \mathrm{~m}$ interval below the $\mathrm{KTB})$ and

706 Gamsbach ( $0.4 \mathrm{~m}$ interval below the KTB) despite their different paleogeography,

707 paleobathymetry, depositional conditions and faunal assemblages, suggesting a common

708 cause. An increase in the proportion of dissolved tests (in addition to physically

709 fragmented ones) in Bidart and Gamsbach confirm the contribution of chemical leaching

710 as cause for imperfect carbonate tests with holes. This implies that water column

711 acidification is a likely cause for the observed increase in FI.

712 Benthic foraminifera are well preserved and even pristine looking in the same 
713 samples alongside leached and fragmented planktic foraminiferal tests at Bidart and

714 Gamsbach (Plates 2, 3). This may indicate acidification restricted to the upper water

715 column, or may reflect the inherently more robust mechanically resistant benthic tests.

716 Alegret et al. (2004; fig. 4) noted an increase in the proportion of agglutinated

717 foraminifera relative to calcareous benthic foraminifera in the top $10-\mathrm{cm}$ of the

718 Maastrichtian at Bidart. We confirm these to be arenaceous (do not dissolve with 1:1

$719 \mathrm{HCl}$ ), which may be interpreted as a consequence of ocean acidification or dissolution.

720 Only in the KTB red clay layer are benthic species corroded suggesting that low $\mathrm{pH}$

721 acidic waters reached through the water column into deeper waters precisely at the KT

722 boundary event. However, the benthic species were little affected by the KTB mass

723 extinction or ocean acidification as their survival is globally documented (Widmark and

724 Malmgren, 1992; Alegret et al., 2001, 2003. Alegret and Thomas, 2004). For the most

725 part preceding the $\mathrm{KTB}$, ocean acidification was restricted to the upper water column

726 with surface waters in equilibrium with very high atmospheric $p \mathrm{CO}_{2}$ and low $\mathrm{CO}_{3}{ }^{2-}$

727 concentrations. Dissolution of test calcite during sinking through the water column would

728 make tests more fragile in post-depositional transport. The degree of

729 dissolution/fragmentation appears to be largely affected by local paleobathymetry and

730 species composition of the assemblage.

731 At Elles, the percentage of fragments is high throughout zone CF1 owing to

732 greater bottom water currents at shallower depths and also dominance of thin-walled

733 fragile heterohelicids in the assemblage (Fig. 10). In contrast, at Bidart the overall test

734 fragmentation is quite low due to a high proportion of structurally more robust

735 globotruncanids and quieter deposition at a greater depth. However, the proportion of 
736 leached out tests with holes due to dissolution increased (Fig. 10; red). At Gamsbach, the

737 degree of fragmentation is high throughout zone CF1 despite a high abundance of

738 globotruncanids. This can be attributed to the frequent turbiditic activity at this site that

739 may have increased post-depositional transport and fragmentation. The variable lithology

740 (deposition of quartz rich beds/lenses) may have facilitated pore-water dissolution,

741 recrystallization-cementation leading to lithified sediments that are difficult to

742 disaggregate and free individual tests.

\section{$744 \quad 8.5$ Ocean acidification: The missing link to Deccan Volcanism?}

745 The main phase-2 of Deccan volcanism occurred over $\sim 750$ kyr entirely within

746 chron C29r, straddling the KTB (Schoene et al., 2014). However, all volcanism did not

747 occur at uniform intensity within this interval, as inferred from the multiple eruptive

748 events of geologically short duration separated by red/green boles indicating periods of

749 quiescence (Subbarao et al., 2000; Jay and Widdowson, 2008; Chenet et al., 2007, 2008).

750 Four of the Deccan phase-2 longest lava-flows across the Indian sub-continent (likely

751 signifying peak volcanic activity) erupted within a duration of 250 kyr (zone CF2-CF1)

752 as seen in the Krishna-Godavari basin, India. The overlying Danian zone P1a sediments

753 constrain the age of the KTB mass extinction as coincident with the final mega-flow of

754 the peak phase-2 eruptions. (Keller et al., 2011a, 2012). The resultant cumulative loading

755 of 12,000-28,000 Gigatons (Gt) of $\mathrm{CO}_{2}$ into the end Cretaceous atmosphere within tens

756 of thousand years could increase the $p \mathrm{CO}_{2}$ on timescales that are recorded in the

757 sediments. This excess $\mathrm{CO}_{2}$ equilibrates with surface ocean water thus altering the

758 carbonate chemistry. The carbonic acid $\left(\mathrm{H}_{2} \mathrm{CO}_{3}\right)$ formed dissociates to bicarbonate anion 
$759\left(\mathrm{HCO}_{3}^{-}\right)$and $\mathrm{H}^{+}$ions, reducing the $\mathrm{pH}$ of surface waters. These $\mathrm{H}^{+}$ions combine with $760 \mathrm{CO}_{3}{ }^{2-}$ anions forming more $\mathrm{HCO}_{3}{ }^{-}$and decreasing the bioavailability of $\mathrm{CO}_{3}{ }^{2-}$ to 761 calcifying organisms to build their tests.

762 The episodic release of hundreds to thousands of teragrams of volcanogenic $\mathrm{SO}_{2}$

763 per year for each Deccan eruption would form sulfate aerosols upon reaction with

764 atmospheric water vapor and precipitate out as toxic acid rain locally/regionally

765 centennial timescales, shorter than the millennial timescales for removal of $\mathrm{CO}_{2}$ (Self et

766 al., 2008; Chenet et al., 2009; Mussard et al., 2014; Callegaro et al., 2014). This could

767 have been directly toxic/lethal for continental flora and fauna of affected areas. On land,

768 acid rain would exacerbate continental weathering. Sulfur dioxide would also lower the

769 surface ocean $\mathrm{pH}$ further, significantly contributing to the calcification crisis and high-

770 stress conditions for calcifying organisms on shorter timescales.

771 Ocean acidification has been identified as an important mechanism associated

772 with faunal turnovers and mass extinction events through geological history (e.g. ocean

773 anoxic events (OAEs) of the Paleozoic and the Paleocene-Eocene thermal maximum

774 (PETM)) that have affected marine calcifiers e.g. coccolithophores, planktic and benthic

775 foraminifera (review in Hönisch et al., 2012). Physiological manifestations of high-stress

776 due to acidification recorded as dwarfism, deformed tests, and R- strategist-dominated

777 assemblages in the Late Maastrichtian have already been linked with phase-2 Deccan

778 volcanism (Erba et al., 2010; review in Punekar et al., 2014a). Moy et al. (2009) reported

779 a 30\%-35\% lower calcification in modern Globigerina bulloides from the Southern

780 Ocean as compared to Holocene specimens. The anthropogenic $\mathrm{CO}_{2}$ emissions have

781 resulted in acidification of the Southern Ocean in the past $\sim 300 \mathrm{yr}$ (drop in pH by 0.1 
782 units, expected drop of 0.7 units in the next $\sim 300 \mathrm{yr}$; Orr et al., 2005; Zeebe et al., 2008).

783 Carbonate tests of planktic organisms can experience dissolution in the water column as

784 demonstrated by the in vitro pteropod shell dissolution within 48 hours of exposure to

785 low pH waters (Fabry et al., 2008; Doney et al., 2009). The cumulative effect of thinner

786 walled tests undergoing water-column dissolution can render a test increasingly fragile

787 and vulnerable to fragmentation, consistent with our taphonomic evidence for ocean 788 acidification.

789 There are multiple lines of evidence in support of global surface ocean 790 acidification associated with the main phase-2 Deccan volcanism: (1) intensely corroded

791 carbonate tests and rapid extinctions of Maastrichtian planktic foraminifera in the

792 intertrappean sediments of the lava mega-flows in the Krishna-Godavari Basin of India

793 (Keller et al., 2011a, 2012). (2) Strong carbonate dissolution and high-stress

794 environments indicated by intense Guembelitria blooms (>95\%) in CF1 of Meghalaya

795 (NE India) (Gertsch et al., 2011). And (3) evidence for iron oxide dissolution by

796 acidification inferred from low MS as well as for surface ocean acidification near the end

797 of zone CF1 preceding the KTB at distal sites such as Bidart (France) and Gamsbach

798 (Austria) as documented in this study.

799

800 9. Conclusions

801 Good temporal correlation between the age of the main phase of Deccan volcanic 802 eruptions in India and the age and episodic nature of climate fluctuations worldwide has

803 strengthened the case for large scale volcanism as a significant contributor to the Late 804 Maastrichtian biotic stress that culminated in the KTB mass extinction. However, 
805 inherent limitations due to incompleteness of the stratigraphic record and the lack of a

806 convincing kill-mechanism have inspired strong skepticism for this hypothesis.

807 A multi-proxy study of the Late Maastrichtian zone CF1 in Bidart (France) and

808 Gamsbach (Austria) reveals events in the final $\sim 160 \mathrm{ky}$ of the Late Maastrichtian that are

809 critical to understanding the role of Deccan volcanism in global high stress environments

810 and leads to the following conclusions.

811 - The Late Maastrichtian warm event in the lower part of zone CF1 at Bidart

812 (France) and Gamsbach (Austria) is recognized by faunal responses similar to

813 those observed at Elles (Tunisia) and DSDP Site 525A.

814 - A period of low $\delta^{13} \mathrm{C}$ values and decreased percent $\mathrm{CaCO}_{3}$ content during the 815 global warming may record a combination of increased continental ${ }^{12} \mathrm{C}$ influx

816 through increased runoff, suppressed primary and calcifier productivity and 817 equilibration of surface ocean waters with increased isotopically lighter $818 \quad$ volcanogenic $\mathrm{CO}_{2}$.

819 - An increase in carbonate dissolution and foraminiferal test fragmentation 820 suggests surface ocean acidification in $60-\mathrm{cm}$ immediately preceding the KTB 821 at Bidart (France) and Gamsbach (Austria). This event globally correlates 822 with the low MS interval defined as the Deccan benchmark interval in Bidart 823 by Font et al., (2011, 2014).

- The widespread ocean acidification interval is coincident with the rapid 825 cooling. At Elles, evidence for another rapid warming following this interval 826 coincides with the KTB mass extinction. The acidification may be the result 827 of equilibration with huge amounts of $\mathrm{CO}_{2}$ injected rapidly into the 


\section{Acknowledgements:}

831 This research was supported by Princeton University's Scott and Tuttle Funds, the U.S. 832 National Science Foundation (grants NSF EAR-0207407, EAR-0447171 and EAR833 1026271) and FCT (ref. PTDC/CTE-GIX/117298/2010). We thank the three anonymous

834 reviewers and the Guest Editor Prof. Wolfram M. Kürschner for their insightful 835 comments and suggestions.

836

837 REFERENCES

838

839 Abrajevitch, A., Hori, R. S., and Kodama, K., 2013. Rock magnetic record of the 840 Triassic-Jurassic transition in pelagic bedded chert of the Inuyama section, Japan. 841 Geology, 41(7), 803-806.

843 Abramovich, S. and Keller, G., 2002. High stress late Maastrichtian paleoenvironment: 844 inference from planktonic foraminifera in Tunisia. Palaeogeography, 845 Palaeoclimatology, Palaeoecology, 178(3), 145-164. doi: 10.1016/S0031$846 \quad 0182(01) 00394-7$

848 Abramovich, S. and Keller, G., 2003. Planktonic foraminiferal response to the latest 849 Maastrichtian abrupt warm event: a case study from South Atlantic DSDP Site 
853 Abramovich, S., Keller, G., Berner, Z., Cymbalista, M., and Rak, C., 2011. Maastrichtian Planktic Foraminiferal Biostratigraphy and Paleoenvironment of Brazos River,

858 Abramovich, S., Keller, G., Stüben, D. and Berner, Z., 2003. Characterization of late Publication, 123-156. doi: 10.1017/S0016756812001069

865 Paleoceanography, 25, PA2201. doi:10.1029/2009PA001843.

867 Adatte, T., Keller, G. and Stinnesbeck, W., 2002. Late Cretaceous to early Paleocene 868 climate and sea-level fluctuations. Paleogeography, Paleoclimatology, 869 Paleoecology, 178, 165-198. doi: 10.1016/S0031-0182(01)00395-9

870

871 Adatte, T., Keller, G., Stüben, D., Harting, M., Kramar, U., Stinnesbeck, W., 872 Abramovich, S. and Benjamini, C., 2005. Late Maastrichtian and K/T 
873

874

875

876

877

878

879

880

881

882

883

884

885

886

887

888

889

890

891

892

893

894

895

paleoenvironment of the eastern Tethys (Israel): mineralogy, trace element and platinum group elements, biostratigraphy and faunal turnovers. Bulletin Société Géologique de France, 176(1), 35-53. doi: 10.2113/176.1.37

Adatte, T., Stinnesbeck, W. and Keller, G. 1996. Lithostratigraphic and mineralogic correlations of near K/T boundary sediments northeastern Mexico: implications for origin and nature of deposition. The Cretaceous-Tertiary Event and Other Catastrophes in Earth History, Boulder, Colorado. Geological Society of America Special Papers, 307, 211-226.

Alegret, L. and Thomas, E., 2004. Benthic foraminifera and environmental turnover across the Cretaceous/Paleogene boundary at Blake Nose (ODP Hole 1049C, Northwestern Atlantic). Palaeogeography, Palaeoclimatology, Palaeoecology, 208(1), 59-83. doi: 10.1016/j.palaeo.2004.02.028

Alegret, L., Kaminski, M. A. and Molina, E., 2004. Paleoenvironmental recovery after the Cretaceous/Paleogene boundary crisis: evidence from the marine Bidart section (SW France). Palaios, 19(6), 574-586. doi: 10.1669/08831351(2004)019<0574:PRATPB>2.0.CO;2

Alegret, L., Molina, E. and Thomas, E., 2001. Benthic foraminifera at the CretaceousTertiary boundary around the Gulf of Mexico. Geology, 29(10), 891-894. doi: 10.1130/0091-7613(2001)029<0891:BFATCT>2.0.CO;2 
897 Alegret, L., Molina, E. and Thomas, E., 2003. Benthic foraminiferal turnover across the Cretaceous/Paleogene boundary at Agost (southeastern Spain): paleoenvironmental inferences. Marine Micropaleontology, 48(3), 251-279. doi:

902 Apellaniz, E., Baceta, J. I., Bernaola-Bilbao, G., Núñez-Betelu, K., Orúe-Etxebarría, X., 903 Payros, A., Pujalte, V., Robin, E. and Rocchia, R., 1997. Analysis of uppermost 904 Cretaceous-lowermost Tertiary hemipelagic successions in the Basque Country 905 (western Pyrenees): evidence for a sudden extinction of more than half planktic 906 foraminifer species at the K/T boundary. Bulletin de la Societé Géologique de 907 France, 168, 783-793.

908 Arenillas, I., Arz, J. and Molina, E., 2004. A new high-resolution planktic foraminiferal 909 zonation and subzonation for the lower Danian. Lethaia, 37(1), 79-95. doi: $10.1080 / 00241160310005097$

911

912 Arz, J. A. and Arenillas, I., 1998. Extinción en masa catastrófica de foraminíferos 913 planctónicos en el límite Cretácico/Terciario del Pirineo occidental (España). 914 Sociedad Mexicana de Paleontología Revista, 8(2), 146-162. doi:

$915 \quad 10.1155 / 2013 / 643278$

916

917 Arz, J. A. and Molina, E., 2002. Late Campanian and Maastrichtian biostratigraphy and 918 chronostratigraphy based on planktic foraminifera in temperate and subtropical 
latitudes (Spain, France and Tunisia). Neues Jahrbuch fur Geologie und Palaontologie-Abhandlungen, 224(2), 161-195.

921

922 Berger, W. H., Bonneau, M. C. and Parker, F. L., 1982. Foraminifera on the deep-sea 923 floor-lysocline and dissolution rate. Oceanologica Acta, 5(2), 249-258.

925 Berggren, W.A., Kent, D.V., Swisher, C.C. and Aubry, M. P. 1995. A revised Cenozoic 926 geochronology and chronostratigraphy. In: Berggren, W.A., Kent, D.V., Aubry, M. P., Hardenbol, J., eds., Geochronology, Time Scales and Global Stratigraphic Correlation. SEPM Special Publication 54, 129-212. doi: 10.2110/pec.95.04.0129

930 Bonté, P., Delacotte, O., Renard, M., Laj, C., Boclet, D., Jehanno, C., and Rocchia, R., 931 1984. An iridium rich layer at the Cretaceous/Tertiary boundary in the Bidart section (southern France). Geophysical Research Letters, 11(5), 473-476. doi: 10.1029/GL011i005p00473

934

935 Callegaro, S., Baker, D. R., De Min, A., Marzoli, A., Geraki, K., Bertrand, H., Viti, C., 936 and Nestola, F., 2014. Microanalyses link sulfur from large igneous provinces and 937 Mesozoic mass extinctions. Geology, 42(10), 895-898. doi: 10.1130/G35983.1

939 Cande, S. and Kent, D.V. 1995. Revised calibration of the geomagnetic polarity 940 Timescale for the Late Cretaceous and Cenozoic. Journal of Geophysical 941 Research, 100, 6093-6095. doi: 10.1029/94JB03098 
943 Caron, M., 1985. Cretaceous planktic foraminifera. In: Bolli, H.M., Saunders, J.B. and

944 Perch-Nielsen, K., eds. Plankton Stratigraphy: Cambridge, Cambridge University 945 Press, $17-86$.

946 Chenet, A. -L., Fluteau, F., Courtillot, V., Gérard, M., and Subbarao, K. V., 2008.

947 Determination of rapid Deccan eruptions across the Cretaceous-Tertiary boundary 948 using paleomagnetic secular variation: Results from a 1200-m-thick section in the 949 Mahabaleshwar escarpment. Journal of Geophysical Research, 113(B4). doi: $950 \quad 10.1029 / 2006 J B 004635$

951 Chenet, A., -L, Quidelleur, X., Fluteau, F., Courtillot, V., and Bajpai, S., 2007. 40K952 40Ar dating of the Main Deccan large igneous province: Further evidence of KTB 953 age and short duration. Earth and Planetary Science Letters, 263(1-2), 1-15. doi: $954 \quad$ 10.1016/j.eps1.2007.07.011

955 Clauser, S., 1994. Etudes stratigraphiques du Campanien et du Maastrichtien de l'Europe 956 Occidentale: Cote Basque, Charentes (France), Limbourg (Pays-Bas). Documents 957 du Bureau de Recherches Géologiques et Minières, 235, 243.

958

959 Coccioni, R. and Marsili, A., 2007. The response of benthic foraminifera to the K-Pg 960 boundary biotic crisis at Elles (northwestern Tunisia). Palaeogeography, $961 \quad$ Palaeoclimatology, $\quad$ Palaeoecology, $\quad 255(1), \quad$ 157-180. 962 doi:10.1016/j.palaeo.2007.02.046 
964 Cowie , J. W., Ziegler, W. and Remane, J., 1989. Stratigraphic Commission accelerates progress, 1984 to 1989 . Episodes, 12, 79-83.

966

967 Dekkers, M. J., 1997. Environmental magnetism: an introduction. Geologie en 968 Mijnbouw, 76(1-2), 163-182.

969

970 Delacotte, O., 1982. Etude magnétostratigraphique et géochimique de la limite Crétacé971 Tertiaire de la coupe de Bidart (Pyrennées Atlantiques). PhD thesis. Université 972 Pierre et Marie Curie, Paris, France.

973

974 Doney, S.C., Fabry, V.J., Feely, R.A., and Kleypas, J.A., 2009. Ocean acidifi cation:

975 The other CO2 problem. Annual Review of Marine Science, 1, 169-192, 976 doi:10.1146/annurev.marine.010908.163834.

977

978 Egger, H., Koeberl, C., Wagreich, M., and Stradner, H., 2009. The Cretaceous-Paleogene $979(\mathrm{~K} / \mathrm{Pg})$ boundary at Gams, Austria: Nannoplankton stratigraphy and geochemistry 980 of a bathyal northwestern Tethyan setting. Stratigraphy, 6(4), 333-347.

981

982 Egger, H., Rögl, F., and Wagreich, M., 2004. Biostratigraphy and facies of Paleogene 983 deep-water deposits at Gams (Gosau Group, Austria) Annalen des 984 Naturhistorischen Museums Wien, 106A, 281-307. 
986 Ellwood, B., MacDonald, W., Wheeler, C. and Benoist, S., 2003. The K-T boundary in

987

988

989

990

991 Ellwood, B., Tomkin, J., Ratcliffe, K., Wright, M., and Kafafy, A., 2008. High-resolution magnetic susceptibility and geochemistry for the Cenomanian/Turonian boundary

Fabry, V.J., Seibel, B.A., Feely, R.A., and Orr, J.C., 2008. Impacts of ocean acidification on marine fauna and ecosystem processes: ICES Journal of Marine Science: 1007 Journal du Conseil, 65(3), 414-432. doi:10.1093/icesjms/fsn048. GSSP with correlation to time equivalent core. Palaeogeography, Palaeoclimatology, $\quad$ Palaeoecology, 261(1), 105-126. doi:10.1016/j.palaeo.2008.01.005

Erba, E., Bottini, C., Weissert, H.J., and Keller, C.E., 2010. Calcareous nannoplankton response to surface-water acidification around oceanic anoxic event 1a. Science, 329(5990), 428-432, doi:10.1126/science.1188886.

Erbacher, J., Mosher, D. C. and Malone, M. J., 2004. Demerara Rise: Equatorial Cretaceous and Paleogene Paleoceanographic Transect, Western Atlantic. In Proceedings of the Ocean Drilling Program, Initial Reports, 207. 
1009 Font, E. and Abrajevitch, A., 2014. Paleoenvironmental signature of the Deccan Phase 2. $1010 \quad$ Frontiers in Earth Sciences. doi: 10.3389/feart.2014.0002.

1011

1012 Font, E., Nedelec, A., Ellwood, B.B., Mirao, J., and Silva, P.F., 2011. A new sedimentary 1013 benchmark for the Deccan Traps volcanism? Geophysical Research Letters, 38, 1014 L24309. doi: 10.1029/2011GL049824

1015

1016 Font, E., Fabre, S., Nédélec, A., Adatte, T., Keller, G., Veiga-Pires, C., Ponte, J., Mirão, 1017 J., Khozyem, H., and Spangenberg, J. E., 2014. Atmospheric halogen and acid 1018 rains during the main phase of Deccan eruptions: Magnetic and mineral 1019 evidence. Geological Society of America Special Papers, 505, SPE505-18. doi: 1020 $10.1130 / 2014.2505(18)$

1021 Galbrun, B., and Gardin, S., 2004. New chronostratigraphy of the Cretaceous -Paleogene 1022 boundary interval at Bidart (France). Earth and Planetary Science Letters, 224, 1023 19-32. doi: 10.1016/j.eps1.2004.04.043

1024 Gallala, N., 2013. Planktonic Foraminiferal Biostratigraphy and Correlation Across the 1025 Cretaceous-Paleogene Transition at the Tethyan and the Atlantic Realms. $1026 \quad$ Paleontology Journal, 2013.

1027 Gallala, N., Zaghbib-Turki, D., Arenillas, I., Arz, J. A., and Molina, E., 2009. 1028 Catastrophic mass extinction and assemblage evolution in planktic foraminifera 1029 across the Cretaceous/Paleogene (K/Pg) boundary at Bidart (SW France). Marine 1030 Micropaleontology, 72(3), 196-209. doi: 10.1016/j.marmicro.2009.05.001 
1032 Gardin, S., 2002. Late Maastrichtian to early Danian calcareous nannofossils at Elles 1033 (Northwest Tunisia). A tale of one million years across the K-T boundary. 1034 Palaeogeography, Palaeoclimatology, Palaeoecology, 178(3), 211-231.

1035

1036 Georgescu, M. D. and Abramovich, S., 2009. A new Late Cretaceous (Maastrichtian) 1037 serial planktic foraminifer (Family Heterohelicidae) with early planispiral coil and revision of Spiroplecta Ehrenberg, 1844. Geobios, 42(6), 687-698.

1040 Gertsch, B., Keller, G., Adatte, T., Garg, R., Prasad, V., Berner, Z., and Fleitmann, D., 1041 2011. Environmental effects of Deccan volcanism across the Cretaceous-Tertiary 1042 transition in Meghalaya, India. Earth and Planetary Science Letters, 310(3-4), $1043 \quad$ 272-285. doi: $10.1016 /$ j.epsl.2011.08.015

1044 Grachev, A.F. (ed.), 2009. The K/T boundary of Gams (Eastern Alps, Austria) and the 1045 nature of terminal Cretaceous mass extinction. Vienna (Geologische 1046 Bundesanstalt), 199. doi: 10.2205/2009-GAMSbook

1048 Grachev, A. F., Korchagin , O. A., Kollmann , H. A., Pechersky, D. M. and Tsel 'movich, 1049 V. A., 2005. A new look at the nature of the transitional layer at the K/T boundary 1050 near Gams, Eastern Alps, Austria, and the problem of the mass extinction of the 1051 biota. Russian Journal of Earth Sciences, 7: doi: 10.2205/2005ES000189. 
1053 Gradstein , F., Ogg , J. and Smith , A., 2004. A Geologic Time Scale 2004. Cambridge:

$1054 \quad$ Cambridge University Press, 589.

1055

1056 Gorostidi, A., and Lamolda, M. A., 1995. La nannoflora calcárea y el tránsito KT de la 1057 sección de Bidart (SW de Francia). Revista Española de Paleontología no. 1058 Homenaje al Dr. Guillermo Colom, 153-168.

1059

1060 Grachev, A. F., Borisovsky, S. E., and Grigor'eva, A. V., 2008. The first find of native 1061 rhenium in the transitional clay layer at the Cretaceous/Paleogene boundary in the Gams Section (eastern Alps, Austria). In Doklady Earth Sciences, 422(1), 10651067. MAIK Nauka/Interperiodica. doi: 10.1134/S1028334X08070131

1064

1065 Grachev, A. F., Korchagin, O. A., Kollmann, H. A., Pechersky, D. M. and Tsel'movich, 1066 V. A., 2005. A new look at the nature of the transitional layer at the K/T boundary 1067 near Gams, Eastern Alps, Austria, and the problem of the mass extinction of the 1068 biota. Russian Journal of Earth Sciences, 7(6).

1069

1070 Haslett, S.K., 1994. Planktonic foraminiferal biostratigraphy and palaeoceanography of 1071 the Cretaceous-Tertiary boundary section at Bidart, south-west France, 1072 Cretaceous Research, 15, 179-192. doi: 10.1006/cres.1994.1009

1073

1074 Haubold , H., Scholger, R., Frisch, W., Summesberger, H. and Mauritsch , H. J., 1999.

1075 Reconstruction of the geodynamic evolution of the Northern Calcareous Alps by 
1076

1077

1078

1079 Hönisch, B., Ridgwell, A., Schmidt, D.N., Thomas, E., Gibbs, S.J., Sluijs, A., 1080

1081

1082

1083

1084

1085

1086

1087

1088

1089

1090

1091

1092

1093

1094 Keller, G. and Benjamini, C., 1991. Paleoenvironment of the eastern Tethys in the early 1095

1096

1097

1098 means of paleomagnetism. Physics and Chemistry of the Earth, Part A: Solid Earth and Geodesy (A), 24, 697-703. doi: 10.1016/S1464-1895(99)00101-5
Zeebe, R., Kump, L., Martindale, R.C., Greene, S.E., Kiessling, G., Ries, J., Zachos, J.C., Royer, D.L., Barker, S., Marchitto, T.M., Jr., Moyer, R., Pelejero, C., Ziveri1, P., Foster, G.L., and Williams, B., 2012. The geological record of ocean acidifi cation, Science, 335(6072), 10581063. doi:10.1126/science. 1208277.

Jay, A. E. and Widdowson, M., 2008. Stratigraphy, structure and volcanology of the SE Deccan continental flood basalt province: implications for eruptive extent and volumes. Journal of the Geological Society, 165(1), 177-188. doi: 10.1144/001676492006-062

Keller, G., 2004. Paleoecology of Late Maastrichtian-early Danian planktic foraminifera in the eastern Tethys. Journal of Foraminiferal Research, 34(1), 49-73. Danian, Palaios, 6, 439-464. doi: 10.2307/3514984

Keller, G., Abramovich, S., Adatte, T., and Berner, Z., 2011b, Biostratigraphy, age of the Chicxulub impact, and depositional environment of the Brazos River KTB sequences, in Keller, G., and Adatte, T., eds., The End-Cretaceous Mass 

(SEPM) Special Publication 100, 81-122.

1101 Keller, G., Abramovich, S., Berner, Z., and Adatte, T., 2009. Biotic effects of the Chicxulub impact, K-T catastrophe and sea-level change in Texas. Paleogeogeography, Paleoclimatology, Paleoecology, 271, 52-68. doi: 10.1016/j.palaeo.2008.09.007

1105

1106 Keller, G., Adatte, T., Bhowmick, P. K., Upadhyay, H., Dave, A., Reddy, A. N., and 1107 Jaiprakash, B. C., 2012. Nature and timing of extinctions in Cretaceous-Tertiary planktic foraminifera preserved in Deccan intertrappean sediments of the Krishna-Godavari Basin, India. Earth and Planetary Science Letters, 341, 211-

1111

1112 Keller, G., Adatte, T., Burns, S. J., Tantawy, A. A., 2002a. High-stress paleoenvironment 221. doi: 10.1016/j.eps1.2012.06.021

1116

1117 Keller, G., Adatte, T., Stinnesbeck, W., Luciani, V., Karoui, N. and Zaghbib-Turki, D., 1118 2002b. Paleoecology of the Cretaceous-Tertiary mass extinction in planktic 1119 foraminifera. Paleogeography, Paleoclimatology, Paleoecology, 178, 257-298. 1120 doi: $10.1016 /$ S0031-0182(01)00399-6 
1122 Keller, G., Adatte, T., Stinnesbeck, W., Stuben, D. and Berner, Z. 2001. Age, chemo-

1123

1124

1125

1126 Keller, G., Adatte, T., Stinnesbeck, W., Stüben, D., Kramar, U., Berner, Z., Li, L. and 1127

1130 1133

1134 1135

1136

1138

1140

1141

1142 and biostratigraphy of Haiti spherule-rich deposits: a multi-event K-T scenario. Canadian Journal of Earth Sciences, 38, 197-227. doi: 10.1139/e00-087 Perch-Nielsen, K. V. S., 1997. The Cretaceous-Tertiary transition on the shallow Saharan platform of southern Tunisia. Geobios, 30(7), 951-975.

Keller, G., Adatte, T., Tantawy, A. A., Berner, Z., and Stüben, D., 2007. High Stress Late Cretaceous to early Danian paleoenvironment in the Neuquen Basin, Argentina. Cretaceous Research, 28, 939-960. doi: 10.1016/j.cretres.2007.01.006

Keller, G., Bhowmick, P. K., Upadhyay, H., Dave, A., Reddy, A. N., Jaiprakash, B. C. and Adatte, T., 2011a. Deccan Volcanism Linked to the Cretaceous-Tertiary Boundary Mass Extinction : New Evidence from ONGC Wells in the Krishna-Godavari Basin. Journal of the Geological Society of India, 78, 399-428. doi: 10.1007/s12594-011-0107-3.

Keller, G., Khozyem, H., Adatte, T., Malarkodi, N., Spangenberg, J. E. and Stinnesbeck, W., 2013. Chicxulub impact spherules in the North Atlantic and Caribbean: age constraints and Cretaceous-Tertiary boundary hiatus. Geological Magazine, 150(05), 885-907. 
1143 Keller, G., Li, L. and MacLeod, N., 1995. The Cretaceous/Tertiary boundary stratotype section at

1144 El Kef, Tunisia: How catastrophic was the mass extinction? Paleogeography, 1145 Paleoclimatology, Paleoecology, 119, 221-254. doi: 10.1016/0031-0182(95)00009-7

1146

1147 Keller, G., Lyons, J.B., MacLeod, N., and Officer, C.B., 1993. Is there evidence for 1148 Cretaceous-Tertiary boundary impact deposits in the Caribbean and Gulf of 1149 Mexico? Geology, 21, 776-780. doi: 10.1130/0091-7613(1993)

1150

1151 Keller, G., Stinnesbeck, W., Adatte, T. and Stüben, D., 2003. Multiple Impacts across the 1152 Cretaceous-Tertiary boundary. Earth Science Reviews, 62, 327-363. doi: $1153 \quad 10.1016 / \mathrm{S} 0012-8252(02) 00162-9$

1154

1155 Kuiper, K. F., Deino , A., Hilgen , F. J., Krijgsman, W., Renne , P. R. and Wijbrans , J.

1156

1157

1158

1159

1160

1161

1162 R., 2008. Synchronizing rock clocks of Earth history. Science, 320, 500-504. doi: 10.1126/science. 1154339

1163

1164 Li, L. and Keller, G., 1998a. Maastrichtian climate, productivity and faunal

1165 turnovers in planktic foraminifera in South Atlantic DSDP Sites 525A and 21,

1166 Marine Micropaleontology, 33, 55-86. doi: 10.1016/S0377-8398(97)00027-3

1167 
1168 Li, L. and Keller, G., 1998b. Diversification and extinction in Campanian-Maastrichtian 1169 planktic foraminifera of northwestern Tunisia. Eclogae Geologicae Helveticae, 91, 75-102. doi: 0012-9402/98/010075-28

1171

1172 MacLeod, N. and Keller, G., 1991. Hiatus distributions and mass extinctions at the 1173 Cretaceous/Tertiary boundary, Geology, 19, 497-501. doi: 10.1016/00311174 0182(95)00009-7

1175

1176 Malmgren, B. A., 1987. Differential dissolution of Upper Cretaceous planktonic 1177 foraminifera from a temperate region of the South Atlantic Ocean. Marine $1178 \quad$ Micropaleontology, 11(4), 251-271.

1179

1180 Moore, J. C., Klaus, A. and Bangs, N.L., 1998. Site 1049, Proc. ODP, Initial Reports $1181 \quad$ 171A (1998), 47-91.

1182

1183 Moy, A.D., Howard, W.R., Bray, S.G., and Trull, T.W., 2009. Reduced calcification 1184 in modern Southern Ocean planktonic foraminifera. Nature Geoscience, 1185 2(4), 276-280. doi:10.1038/ngeo460.

1186

1187 Mussard, M., Le Hir, G., Fluteau, F., Lefebvre, V., and Goddéris, Y., 2014, Modeling the 1188 carbon-sulfate interplays in climate changesrelated to the emplacement of 1189 continental flood basalts, in Keller, G., and Kerr, A.C., eds., Volcanism, Impacts, 
and Mass Extinctions: Causes and Effects. Geological Society of America Special Paper 505, doi: 10.1130/2014.2505(17).

1193 Nederbragt, A. J., 1991. Late Cretaceous biostratigraphy and development of 1194 Heterohelicidae (planktic foraminifera). Micropaleontology, 329-372. $1195 \quad 10.2307 / 1485910$

1197 Nelson, B.K., Macleod, G.K. and Ward, P.D., 1991. Rapid change in strontium isotopic 1198 composition of seawater before the Cretaceous/Tertiary boundary. Nature, 351, 644-647. doi: $10.1038 / 351644 a 0$

1200

1201 Olsson, R.K., Hemleben, C., Berggren, W.A. and Huber, B.T., 1999. Atlas of Paleocene 1202 Planktonic Foraminifera. Smithsonian Contribution to Paleobiology No. 85. 1203 Smithsonian Institution Press, Washington D.C., pp. 252.

1205 Orr, J.C., Fabry, V.J., Aumont, O., Bopp, L., Doney, S.C., Feely, R.A., Gnanadesikan, 1206 A., Gruber, N., Ishida, A., Joos, F., Key, R.M., Lindsay, K., 1207 Maier-Reimer, E., Matear, R., Monfray, P., Mouchet, A., Najjar, R.G., 1208 Plattner, G-K., Rodgers, K.B., Sabine, C.L., Sarmiento, J.L., Schlitzer, 1209 R., Slater, R.D., Totterdell, I.J., Weirig, M-F., Yamanaka, Y., and Yool, 1210 A., 2005. Anthropogenic ocean acidification over the twenty-first century 1211 and its impact on calcifying organisms. Nature, 437, 681-686. 1212 doi:10.1038/nature04095. 
1214 Pechersky, D. M., Grachev, A. F., Nourgaliev, D. K., Tsel'movich, V. A. and Sharonova, 1215 Z. V., 2006. Magnetolithologic and magnetomineralogical characteristics of 1216 deposits at the Mesozoic/Cenozoic boundary: Gams section (Austria). Russian 1217 Journal of Earth Sciences, 8(3). doi: 10.2205/2006ES000204.

1219 Peybernes, B., Fondecave-Wallez, M.J., Gourinard, Y., and Eichène, P., 1997. 1220 Stratigraphie séquentielle comparée et grade-datation par les foraminifères

1221 1225

1226 1230

1231 Punekar, J., Keller, G., Khozyem, H., Hamming, C., Adatte, T., Tantawy, A. A. and 1232 1233 1234 Spangenberg, J. E. 2014b. Late Maastrichtian-early Danian high-stress environments and delayed recovery linked to Deccan volcanism. Cretaceous Research, 49, 63-82. 10.1016/j.cretres.2014.01.002 
1236 Punekar, J., Mateo, P., and Keller, G., 2014a. Effects of Deccan volcanism on

1237

1238

1239

1240

1241

1242

1243

1244

1245

1246

1247

1248 Renne, P. R., Deino, A. L., Hilgen, F. J., Kuiper, K. F., Mark, D. F., Mitchell, W. S., 1249

1250

1251

1252

1253 Remane, J., Keller, G., Hardenbol, J., and Ben Haj Ali, M., 1999. Report on the 1254 1255 1256

1257 Renard, M., Delacotte, O., and Létolle, R., 1982. Le strontium et les isotopes stables 1258 paleoenvironment and planktic foraminifera: A global survey. Geological Society of America Special Papers, 505, 91-116. doi: 10.1130/2014.2505(04)

Raja Rao, C.S., Sahasrabudhe, S.S., Deshmukh, S.S. and Raman, R. 1999. Distribution, structure and petrography of the Deccan Traps, India, in: K.V. Subbarao (Ed.), Deccan Volcanic Province, Memoir - Geological Society of India, 43, 401-414.

Razin, P., 1989. Evolution tectono-sédimentaire alpine des Pyrénées Basques à l'Ouest de la transformante de Pampelune (Province du Labourd) (Thèse de doctorat) Université de Bordeaux III, 464. Morgan, L. E., Mundil, R. and Smit, J., 2013. Time scales of critical events around the Cretaceous-Paleogene boundary. Science, 339(6120), 684-687. doi: 10.1126/science. 1230492 International Workshop on Cretaceous-Paleogene Transitions: Episodes, 22(1), $47-48$. dans les carbonates totaux de quelques sites de l'Atlantique et de la Tethys. 
Bulletin de la Société Géologique de France, 14, 519-534. doi:

1262 Robaszynski, F., Caron, M., Gonzalez-Donoso, J. M., Wonders, A. H., Ewgpf 19831263 1984. Paris Atlas of late Cretaceous Globotruncanids. Revue de 1264 Micropaléontologie, 36 (3-4), 145-305.

1265

1266 Rocchia, R., Boclet, D., Bonté, Ph., Devineau, J., Jéhanno, C. and Renard, M., 1987. Comparaison des distributions de l'iridium observéesàla limite Crétacé-Tertiaire dans divers sites européens. Mémoires de la Société géologique de France N.S.,

1270

1271 Rocchia, R., Robin, E., Froget, L. and Gayraud, J. 1996. Stratigraphic distribution of 1272 extraterrestrial markers at the Cretaceous-Tertiary boundary in the Gulf of Mexico area: Implications for the temporal complexity of the event. Geological Society of

1275

1276 Schöbel, S., de Wall, H., Ganerød, M., Pandit, M. K., and Rolf, C., 2014. 1277 Magnetostratigraphy and 40Ar-39Ar geochronology of the Malwa Plateau region 1278 (Northern Deccan Traps), central western India: Significance and correlation with 1279 the main Deccan Large Igneous Province sequences. Journal of Asian Earth $1280 \quad$ Sciences, 89, 28-45. doi: 10.1016/j.jseaes.2014.03.022 
1282 Schoene, B., Samperton, K., Eddy, M., Keller, G., Adatte, T., Bowring, S., Khadri, S. F. 1283 R. and Gertsch, B., 2014. U-Pb geochronology of the Deccan Traps and relation 1284 to the end-Cretaceous mass extinction. Science (aaa0118). 1285 doi:10.1126/science.aaa0118

1286

1287 Shackleton, N. and Boersma, A., 1985. History of the Walvis Ridge. A précis of the 1288 results of DSDP Leg 74 In: Moore, T. C. Jr, Rabinowitz, P. D. and Borella, P. E., $1289 \quad$ eds., South Atlantic Paleoceanography, 57.

1290

1291 Self, S., Blake, S., Sharma, K., Widdowson, M., and Sephton, S., 2008. Sulfur and 1292 chlorine in Late Cretaceous Deccan magmas and eruptive gas release. Science 1293 319, 1654-1657. doi: 10.1126/science. 1152830

1294 Seyve, C., 1984. Le passage Crétacé-Tertiaire à Pont Labau. Bulletin des Centres de 1295 Recherches Exploration-Production Elf-Aquitaine, 8, 385-423.

1296

1297 Smit, J., and ten Kate, W.G.H.Z., 1982. Trace-element patterns at the Cretaceous1298 Tertiary boundary-consequences of a large impact Cretaceous Research, 3, 3071299332.

1300

1301 Stüben, D., Kramar, U., Berner, Z. A., Meudt, M., Keller, G., Abramovich, S., Adatte, T., 1302 Hambach, U. and Stinnesbeck, W. 2003. Late Maastrichtian paleoclimatic and 1303 paleoceanographic changes inferred from $\mathrm{Sr} / \mathrm{Ca}$ ratio and stable isotopes. 
Palaeogeography, Palaeoclimatology, Palaeoecology, 199(1), 107-127. doi:

1307 Subbarao, K.V., Bodas, M.S., Khadri, S.F.R., Beane, J.E., Penrose Deccan 2000, Field 1308 excursion guide to the western Deccan Basalt Province. Penrose Field Guides, B. 1309 Geological Society of India, ed., 2000.

1310

1311 Summesberger, H., Wagreich, M. and Bryda, G. 2009. Upper Maastrichtian cephalopods 1312 and the correlation to calcareous nannoplankton and planktic foraminifera zones 1313 in the Gams Basin (Gosau Group; Styria, Austria). Annalen des Naturhistorischen $1314 \quad$ Museums Wien 111A, 159-182.

1315

1316 Tantawy, A. A., 2003. Calcareous nannofossil biostratigraphy and paleoecology of the 1317 Cretaceous-Tertiary transition in the central eastern desert of Egypt. Marine 1318 Micropaleontology, 47, 323-356. doi: 10.1016/S0377-8398(02)00135-4

1320 Tantawy, A. A., Keller, G. and Pardo, A., 2009. Late Maastrichtian volcanism in the 1321 Indian Ocean: effects on calcareous nannofossils and planktic foraminifera. 1322 Palaeogeography, Palaeoclimatology, Palaeoecology, 284(1), 63-87. 10.1016/j.palaeo.2009.08.025

1324

1325 Thibault, N. and Gardin, S., 2010. The calcareous nannofossil response to the end1326 Cretaceous warm event in the Tropical Pacific. Palaeogeography, 
Palaeoclimatology, Palaeoecology,

291(3),

$239-252$. doi:10.1016/j.palaeo.2010.02.036

1330 Thibault, N., Minoletti, F., Gardin, S., and Renard, M., 2004. Morphométrie de 1331 nannofossiles calcaires au passage Crétacé-Paléocène des coupes de Bidart (France) et d'Elles (Tunisie). Comparaison avec les isotopes stables du carbone et de l'oxygène. Bulletin de la Societe Géologique de France, 175.

Thunell, R. C., 1976. Optimum indices of calcium carbonate dissolution, in deep-sea sediments. Geology, 4(9), 525-528.

1338 Vonhof, H.B. and Smit, J., 1997. High-resolution late Maastrichtian-early Danian oceanic ${ }^{87} \mathrm{Sr} /{ }^{86} \mathrm{Sr}$ record: implications for Cretaceous-Tertiary boundary events. Geology, 25, 347-350. doi: 10.1130/0091-7613(1997)025<0347:HRLMED>

1343 Wagreich, M., 1993. Subcrustal tectonic erosion in orogenic belts - A model for the Late Cretaceous subsidence of the Northern Calcareous Alps (Austria). Geology, 21, 1346

1347 Wagreich, M., 1995. Subduction tectonic erosion and Late Cretaceous subsidence along 1348 the northern Austroalpine margin (Eastern Alps, Austria). Tectonophysics, 242, $1349 \quad$ 63-78. 
1351 Wagreich, M. and Krenmayr, H., -G., 1993. Nannofossil biostratigraphy of the Late 1352 Cretaceous Nierental Formation, Northern Calcareous Alps (Bavaria, Austria). 1353 Zitteliana, 20, 67-77.

1355 Wagreich, M. and Krenmayr, H., -G., 2005. Upper Cretaceous oceanic red beds (CORB) 1356 in the Northern Calcareous Alps (Nierental Formation, Austria): slope topography and clastic input as primary controlling factors. Cretaceous Research, 26, 57-64.

1359 Widmark, J. G. V. and Malmgren, B. A., 1992. Benthic foraminiferal changes across the 1360 Cretaceous/Tertiary boundary in the deep sea; DSDP sites 525, 527, and 465. The 1361 Journal of Foraminiferal Research, 22(2), 81-113.

1363 Williams, D. F., Healy-Williams, N. and Laschak, P., 1985. Dissolution and water-mass 1364 patterns in the southeast Indian Ocean, I, Evidence from Recent to late Holocene 1365 foraminiferal assemblages, Geological Society of America Bulletin, 96, 176-189.

1367 Zeebe, R.E., 2012. History of seawater carbonate chemistry, atmospheric $\mathrm{CO}_{2}$, and ocean 1368 acidification: Annual Review of Earth and Planetary Sciences, 40, 141-165, doi: 10.1146/annurev-earth-042711-105521.

1370

1371 Zeebe, R.E., Zachos, J.C., Caldeira, K., and Tyrrell, T., 2008. Carbon emissions and acidification. Science, 321, 51-52. doi:10.1126/science.1159124. 
1375 Figure 1. Palaegeographic map of 66 Ma showing the study sections Bidart (France) and 1376 Gamsbach (Austria) and the reference section Elles (Tunisia, GSSP) relative to the 1377 location of the Reunion hotspot (focal point of Deccan volcanism). Modified after @2000 1378 C R Scotese PALEOMAP Project.

1380 Figure 2. (A) Lithological log of the upper Maastrichtian-basal Danian interval studied at 1381 Bidart, the red layer marks the KTB (B) Google Earth image showing the present day 1382 location of Bidart (C) Field photograph of the Bidart section showing the sampled 1383 interval and the position of KTB (in red).

1385 Figure 3. (A) Lithological log of the uppermost Maastrichtian interval of Gamsbach, the 1386 red layer marks the KTB (B) Google Earth image showing the present day location of 1387 Gamsbach (C) Field photograph of the Gamsbach section showing the position of KTB 1388 (in red).

1390 Figure 4. The completeness of Bidart and Gamsbach sections relative to Elles (Tunisia) 1391 based on planktic foraminiferal biozonation scheme of Keller et al. (1995; 2002). The 1392 biozone ages can be extrapolated using a KTB age of 65.5 Ma (Gradstein et al., 2004) or 1393 66.04 Ma (Renne et al., 2013). Hiatuses are observed at the KTB and at the P1a(1)/P1a(2) 1394 transition at Bidart. A major hiatus is identified at the KTB at Gamsbach due to missing 1395 zones P0, P1a(1) and early P1a(2). 
1397 Figure 5. (A) Key foraminifera and geochemical attributes of the KTB boundary and 1398 lower Danian at Bidart (B) Abundance of late Maastrichtian planktic foraminifera of the $139963-150 \mu \mathrm{m}$ size fraction and the KTB mass extinction. The $\delta^{13} \mathrm{C}$ record shows the 1400 characteristic $\sim 2 \%$ negative shift at the KTB.

1402 Figure 6. (A) Faunal and geochemical changes at the KTB boundary and in the lower 1403 Danian of Gamsbach. (B) Late Maastrichtian planktic foraminifera of the $>150 \mu \mathrm{m}$ size 1404 fraction and the KTB mass extinction. The $\delta^{13} \mathrm{C}$ record shows $\sim 1.3 \%$ onegative shift at the 1405 KTB.

1407 Figure 7. A comparison of the relative abundances of some key species $(63-150 \mu \mathrm{m})$ in 1408 the upper Maastrichtian zone CF1 assemblage of (A) Elles (Tunisia) and (B) Bidart 1409 (France). Note that Heterohelix dentata, H. globulosa and Pseudoguembelina costulata 1410 dominate the assemblage in Elles, in contrast to Bidart where they are rare. Whole-rock $1411 \quad \delta^{13} \mathrm{C}$ and $\delta^{18} \mathrm{O}$ are shown.

1413 Figure 8. A comparison of the relative abundances of some key species $(>150 \mu \mathrm{m})$ in the 1414 Late Maastrichtian zone CF1 assemblage of (A) Elles (Tunisia), (B) Bidart (France) and

1415 (C) Gamsbach (Austria). The deep-water assemblages of Bidart and Gamsbach are very 1416 similar to each other and different from the neritic assemblages of Elles. Planktic $\delta^{13} \mathrm{C}$ 1417 and $\delta^{18} \mathrm{O}$ for Elles are obtained from Rugoglobigerina rugosa and benthic values are 
1418 from Cibicidoides pseudoacuta. Whole-rock isotope data are shown for the Bidart and 1419 Gamsbach sections.

1420

1421 Figure 9. Relative abundances of depth-ranked groups of planktic foraminifera species in

1422 (A) Elles (Tunisia), (B) Bidart (France) and (C) Gamsbach (Austria). Thermocline

1423 dwelling globotruncanids (blue) are more abundant in the $>150 \mu \mathrm{m}$ fraction of Bidart and

1424 Gamsbach (open marine settings) as compared to Elles (neritic setting). Poor preservation

1425 of foraminifera in the $63-150 \mu \mathrm{m}$ fraction of the Gamsbach section precluded quantitative

1426 analysis.

1427

1428 Figure 10. Multi-proxy data shows a dissolution interval immediately preceding the

1429 KTB. A low magnetic susceptibility (MS) interval in the upper part of zone CF1 of Elles,

1430 Bidart and Gamsbach (yellow) marks a regional chemical benchmark of Deccan

1431 volcanism (after Font et al, 2011; 2014). Increased planktic foraminiferal test

1432 fragmentation in the low MS interval supports water column carbonate dissolution.

1433

1434 Figure 11. Magnetic susceptibility (MS) data for Bidart (Font et al., 2011) along with the

1435 fragmentation index (FI) data for planktic and benthic foraminifera. The geochemical

1436 Deccan benchmark interval coincides with a pronounced water column dissolution event

1437 recorded by the planktic foraminifera. The benthic FI for the same interval indicate only a

1438 minor contribution of post-depositional breakage.

1439

1440 
1441 Plate 1. Characteristic taxa of the upper Maastrichtian zone CF1 assemblage at Bidart,

1442 France, scale bar $=100 \mu \mathrm{m}$.

1443 A. Globotruncanita stuarti (de Lapparent), spiral view

1444 B. Abathomphalus mayaroensis (Brönnimann), spiral view

1445 C. Heterohelix rajagopalani Govindan

1446 D. Pseudoguembelina hariaensis Nederbragt

1447 E. Heterohelix globulosa (Ehrenberg)

1448 F. Pseudotextularia elegans (Rzehak)

1449 G. Racemiguembelina fructicosa (Egger)

1450 H. Planoglobulina brazoensis (Martin)

1451 I. Guembelitria cretacea (Cushman)

$1452 \quad$ J. Spiroplecta americana (Ehrenberg)

1453 K. Hartella harti Georgescu \& Abramovich

1454 L. Heterohelix navarroensis (Loeblich)

1455 M. Plummerita aff. hantkeninoides (Brönnimann)

1456 N. Rugoglobigerina macrocephala (Brönnimann)

1457 O. Globigerinelloides volutus (White)

1458 P. Globigerinelloides subcarinatus (Brönnimann)

1460 Plate 2. Planktic foraminifera indicating varying degrees of preservation in the upper

1461 Maastrichtian zone CF1 assemblage at Bidart, France, scale bar $=100 \mu \mathrm{m}$.

1462 (A-L): "Imperfect" tests with minor breakages and/or holes and signs test surface 1463 dissolution 
1464 (M-S): "Fragments" defined by less than two-thirds or the original test preserved.

1465

1466 Plate 3. Benthic foraminifera indicating varying degrees of preservation in the upper

1467 Maastrichtian zone CF1 and the KTB assemblage at Bidart, France, scale bar= $100 \mu \mathrm{m}$.

1468 (A-G): "Perfect" tests with no signs of chemical or mechanical damage

1469 (H-L, O, P): "Imperfect" tests with minor breakages and/or holes and signs test surface

1470 dissolution. Note that the proportion of the tests with holes is maximum at the KTB and

1471 in the early Danian sediments.

1472 (M, N, Q-S): "Fragments" defined by less than two-thirds or the original test preserved.

1473

1474

1475

1476

1477

1478

1479

1480

1481

1482

1483

1484

1485

1486 
Figure1. Paleogeographic Map

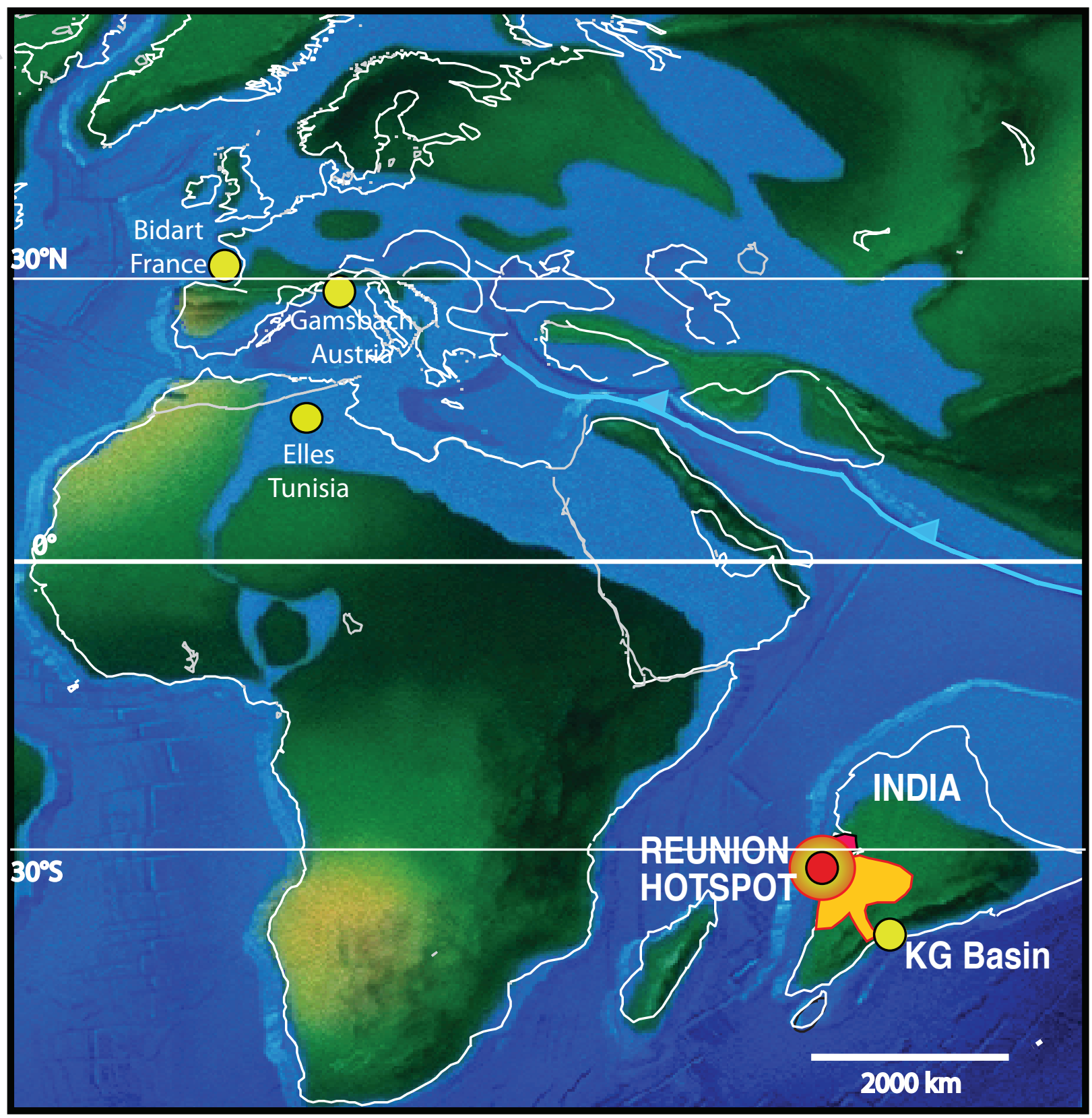




\section{KTB Transition at Bidart (France)}

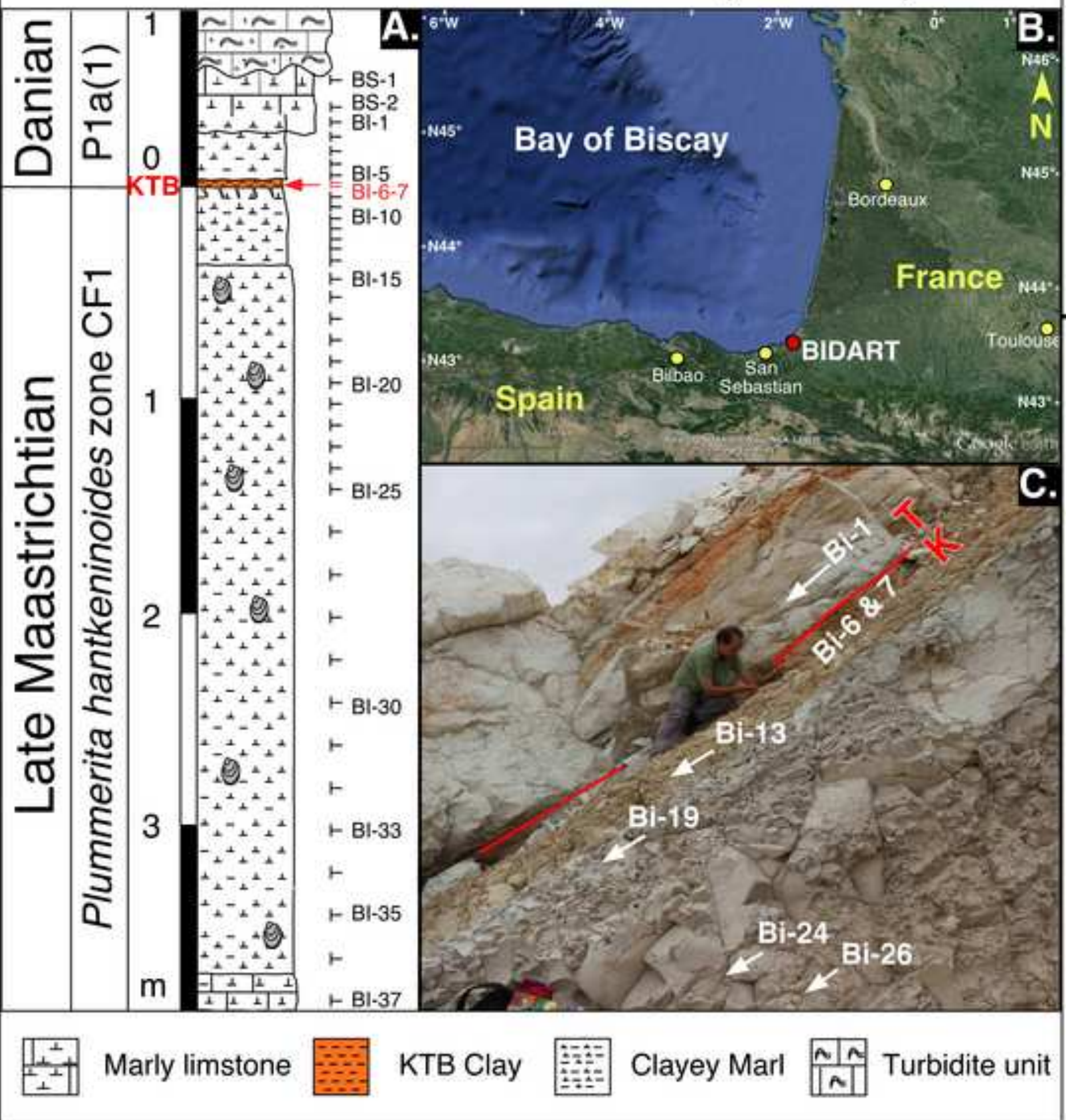




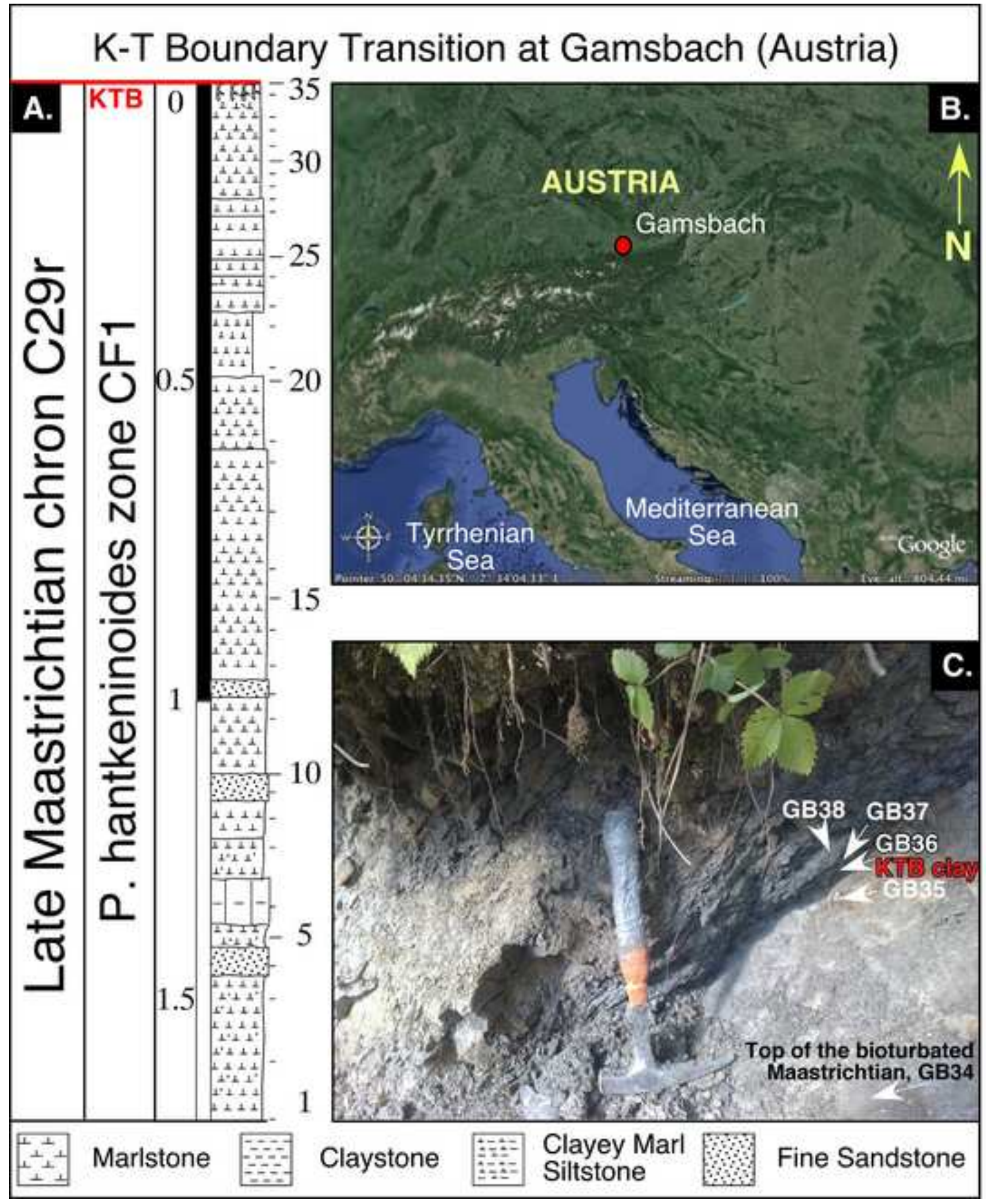




\begin{tabular}{|c|c|c|c|c|c|c|c|c|c|c|c|}
\hline & & $\mathrm{Ca}$ & $\begin{array}{r}\text { Plank } \\
\text { Icareous }\end{array}$ & $\begin{array}{l}\text { ic Fc } \\
\text { Nan }\end{array}$ & $\begin{array}{l}\text { orami } \\
\text { inofo }\end{array}$ & $\begin{array}{l}\text { inifera } \\
\text { ossil Bi }\end{array}$ & $\begin{array}{l}\& \\
\text { ozones }\end{array}$ & $\begin{array}{c}\text { Biozone } \\
\text { Ages }\end{array}$ & Bio & stratigr & hy \\
\hline & $\begin{array}{l}\text { ge }(N \\
\text { g. } P c\end{array}$ & $\begin{array}{l}\text { Ma) } \\
\text { olar. }\end{array}$ & $\begin{array}{l}\text { Berggren et } \\
\text { Huber et al } \\
\text { Tantawy. }\end{array}$ & $\begin{array}{l}\text { 1. } 1995 \\
2008 \\
0003\end{array}$ & & $\begin{array}{l}\text { Li \& Ke } \\
\text { Keller et }\end{array}$ & $\begin{array}{l}\text { ller, 1998a, b } \\
\text { al. 1995, } 2002\end{array}$ & \begin{tabular}{|l} 
KTB: $65.5 \mathrm{Ma}$ \\
Gradstein et al. \\
2004
\end{tabular} & $\begin{array}{c}\text { Gamsbach } \\
\text { Austria }\end{array}$ & $\begin{array}{l}\text { Bidart } \\
\text { France }\end{array}$ & $\begin{array}{l}\text { Elles } \\
\text { Tunisia }\end{array}$ \\
\hline$\stackrel{\overparen{C}}{\text { (ָ) }}$ & & $28 \mathrm{~N}$ & NP1c & P1c & P1c & $\mathrm{P} 1 \mathrm{c}(2)$ & $\begin{array}{l}\text { P. trinidadensis } \\
\uparrow P \text {. inconstans }\end{array}$ & $\begin{array}{c}\mathrm{P} 1 \mathrm{c} \\
\sim 13 \mathrm{mv}\end{array}$ & No data & No data & No data \\
\hline อِ & $\begin{array}{l}64.12 \\
64.43\end{array}$ & & NP1b & P1b & & P1c(1) & A S. varianta & & & & \\
\hline : & & $29 \mathrm{~N}$ & & P1a & & $\mathrm{P} 1 \mathrm{~b}$ & & $\begin{array}{c}\text { P1b } \\
\sim 590 \mathrm{ky}\end{array}$ & P1b & & $\mathrm{P} 1 \mathrm{~b}$ \\
\hline तु & 65.50 & & CP1a & $\mathrm{Pa}$ & P1aL & $\mathrm{P} 1 \mathrm{a}(2)$ & $\begin{array}{l}P \text {. eugubina } \\
\uparrow \text {. pseudobull. }\end{array}$ & $P 0+P 1 a$ & $n$ & & P1a(2) \\
\hline ن & 66.04 & $29 R$ & KTB & & & P1 $1 \mathrm{a}(1)$ & ^ $\begin{array}{c}P \text {. eugubina } \\
\uparrow \text { FA Danian spp. }\end{array}$ & 380 ky & Hiatus & Hiătus & $\begin{array}{l}\mathrm{P} 1 \mathrm{a}(1) \\
\mathrm{PA}\end{array}$ \\
\hline & & & M. prinsii & & & CF1 & A P. hantkenin. & $160 \mathrm{ky}$ & CF1 & CF1 & CF1 \\
\hline एँ & & & CC26b & $\overbrace{0}^{\infty}$ & & CF2 & G. gansseri & $100 \mathrm{ky}$ & & & CF2 \\
\hline$\stackrel{\mathbb{\sigma}}{\Sigma}$ & & $30 N$ & $\begin{array}{c}\text { M. murus } \\
\text { CC26a }\end{array}$ & $\frac{\text { क्षे }}{2}$ & P. hal & $\begin{array}{l}\text { CF3 } \\
\text { ariaensis }\end{array}$ & & & No Uata & No dald & CF3 \\
\hline 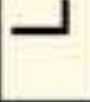 & & & & & & & A $P$. hariaensis & & & & \\
\hline
\end{tabular}




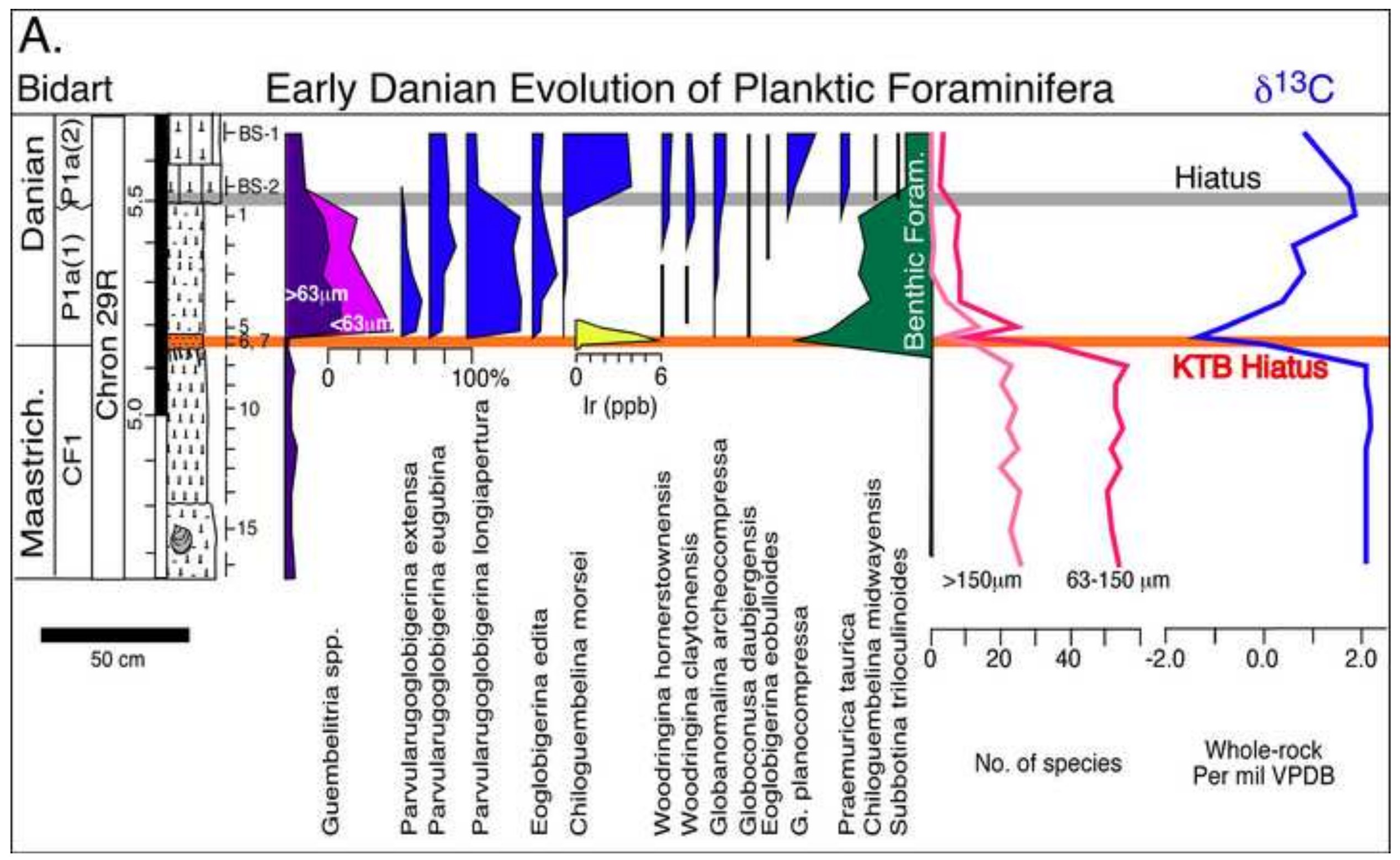




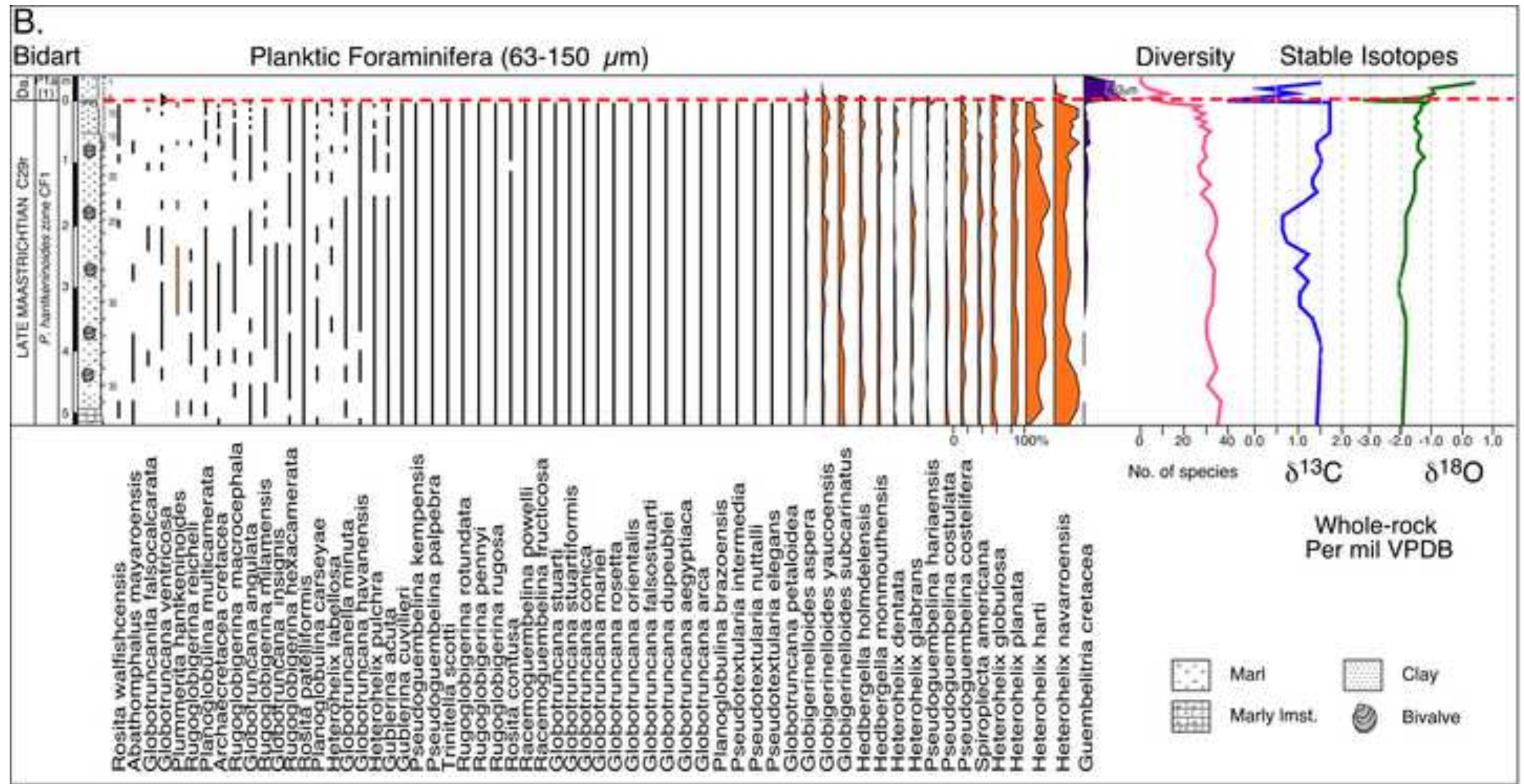




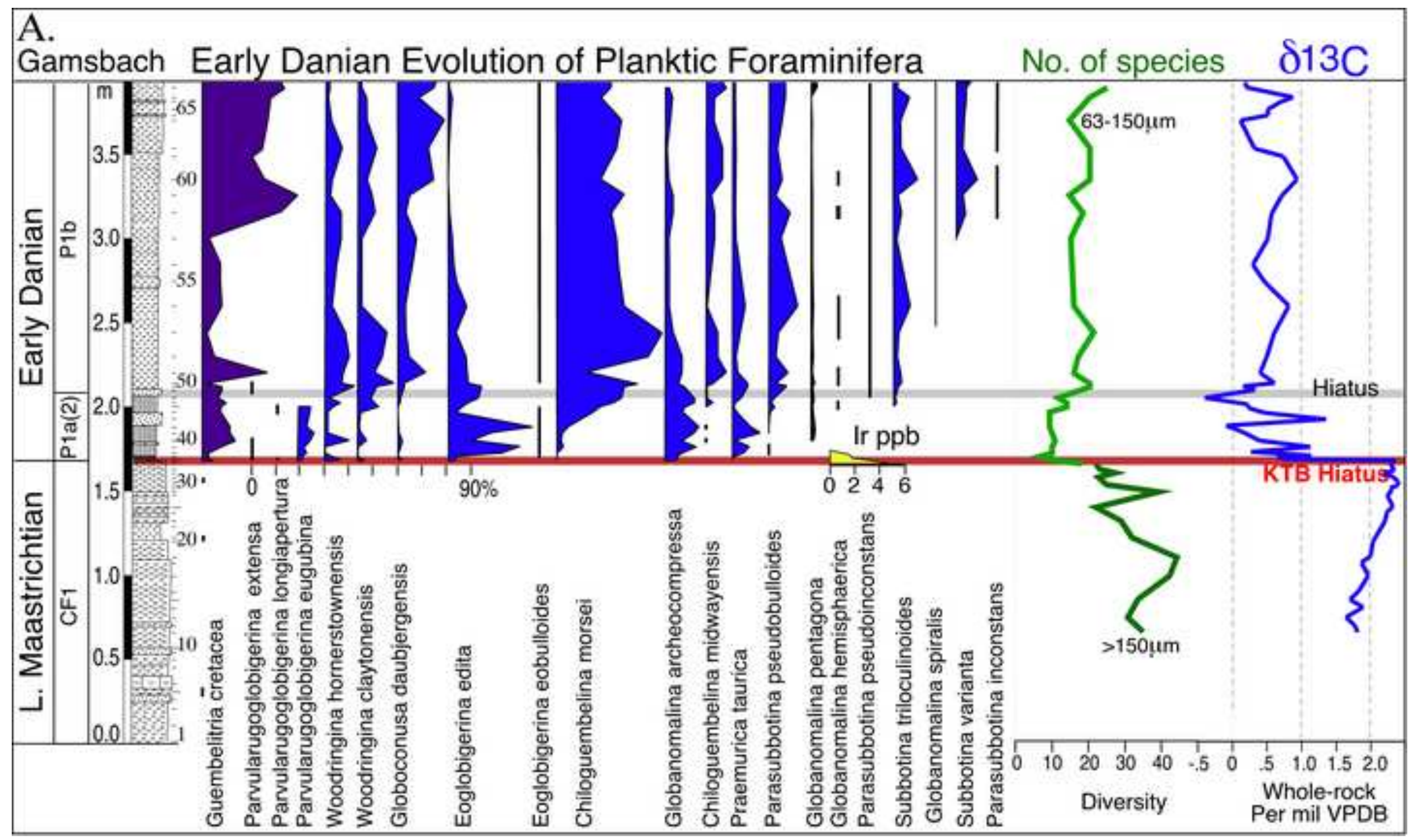




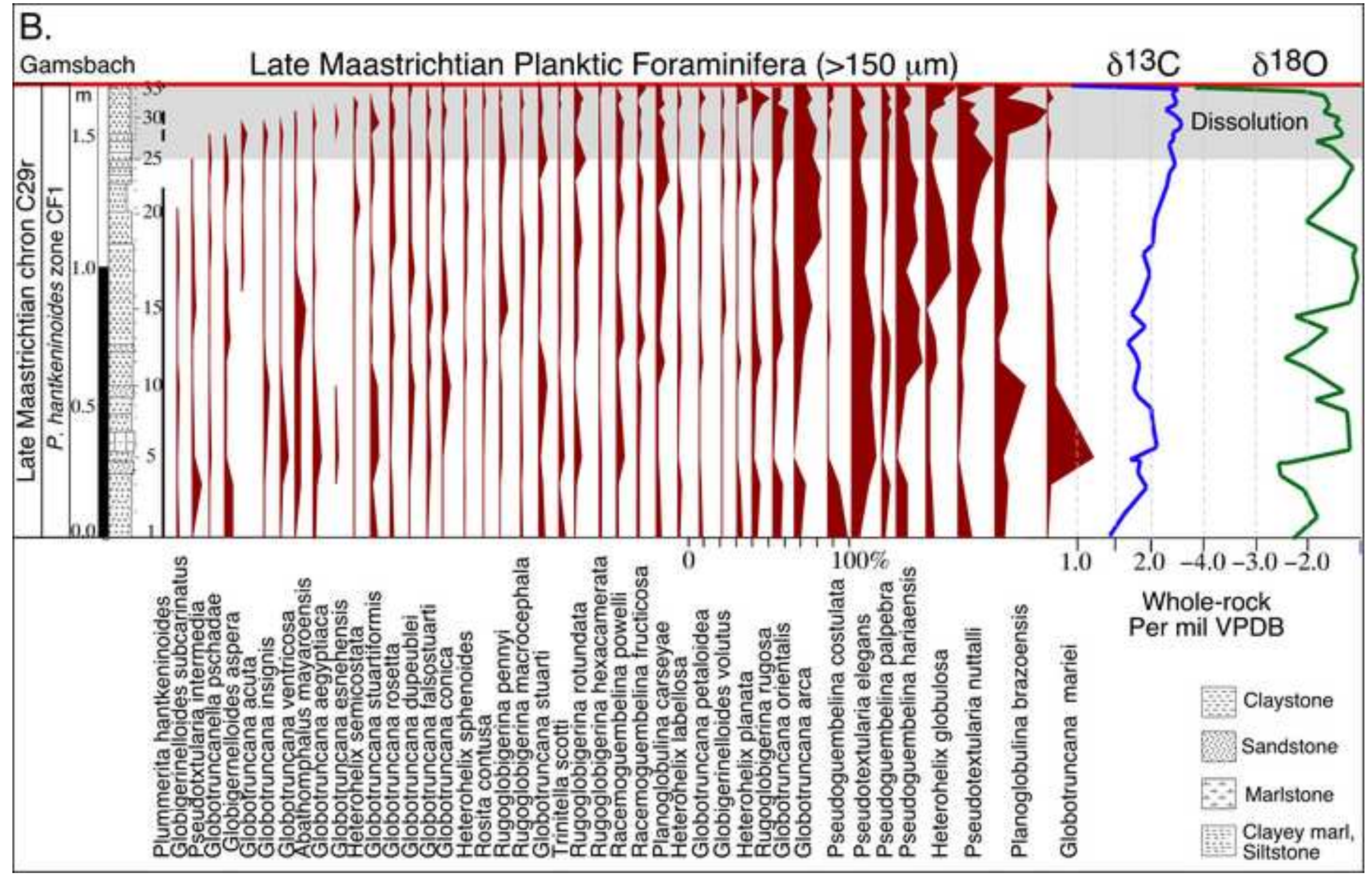




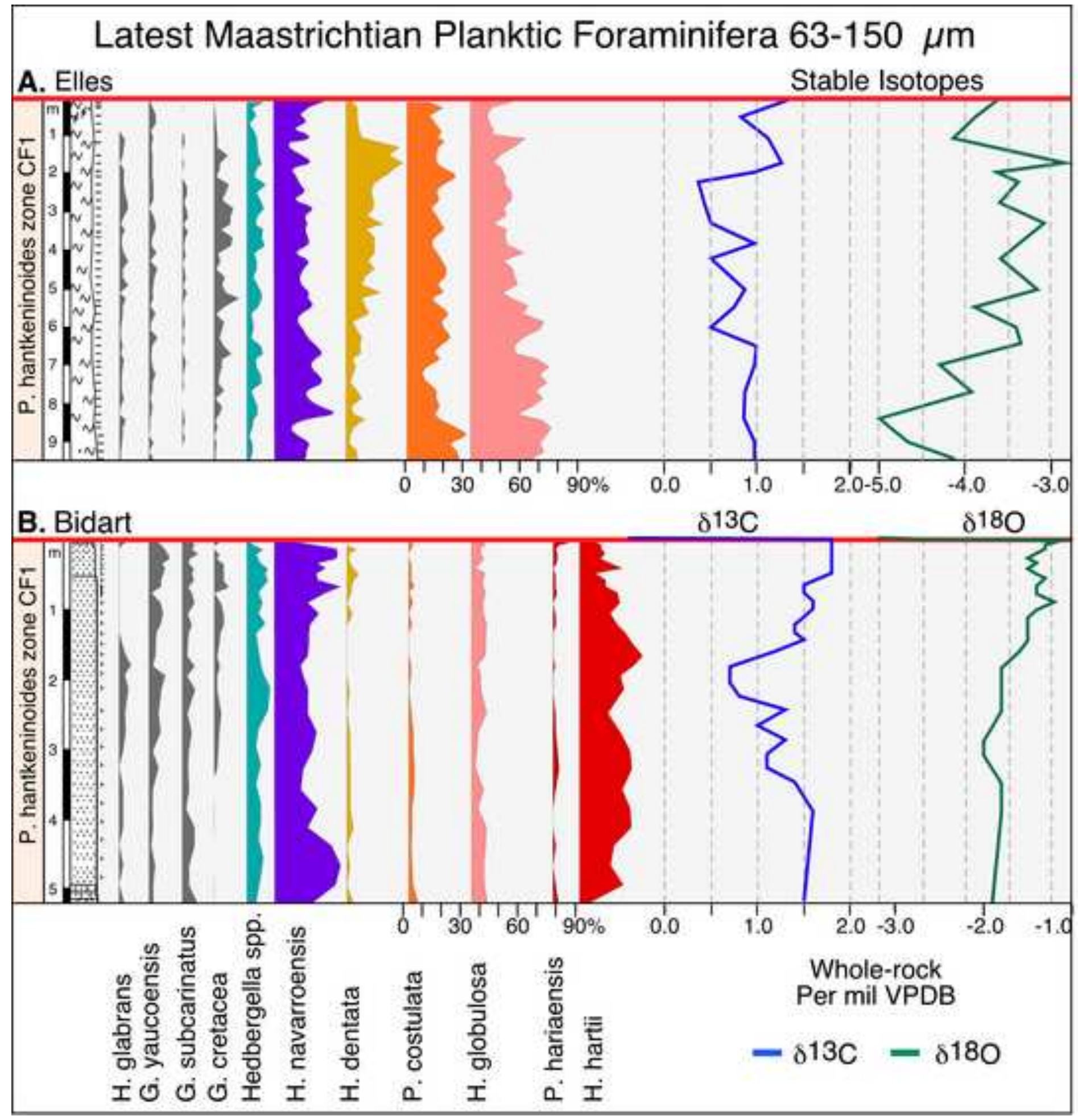




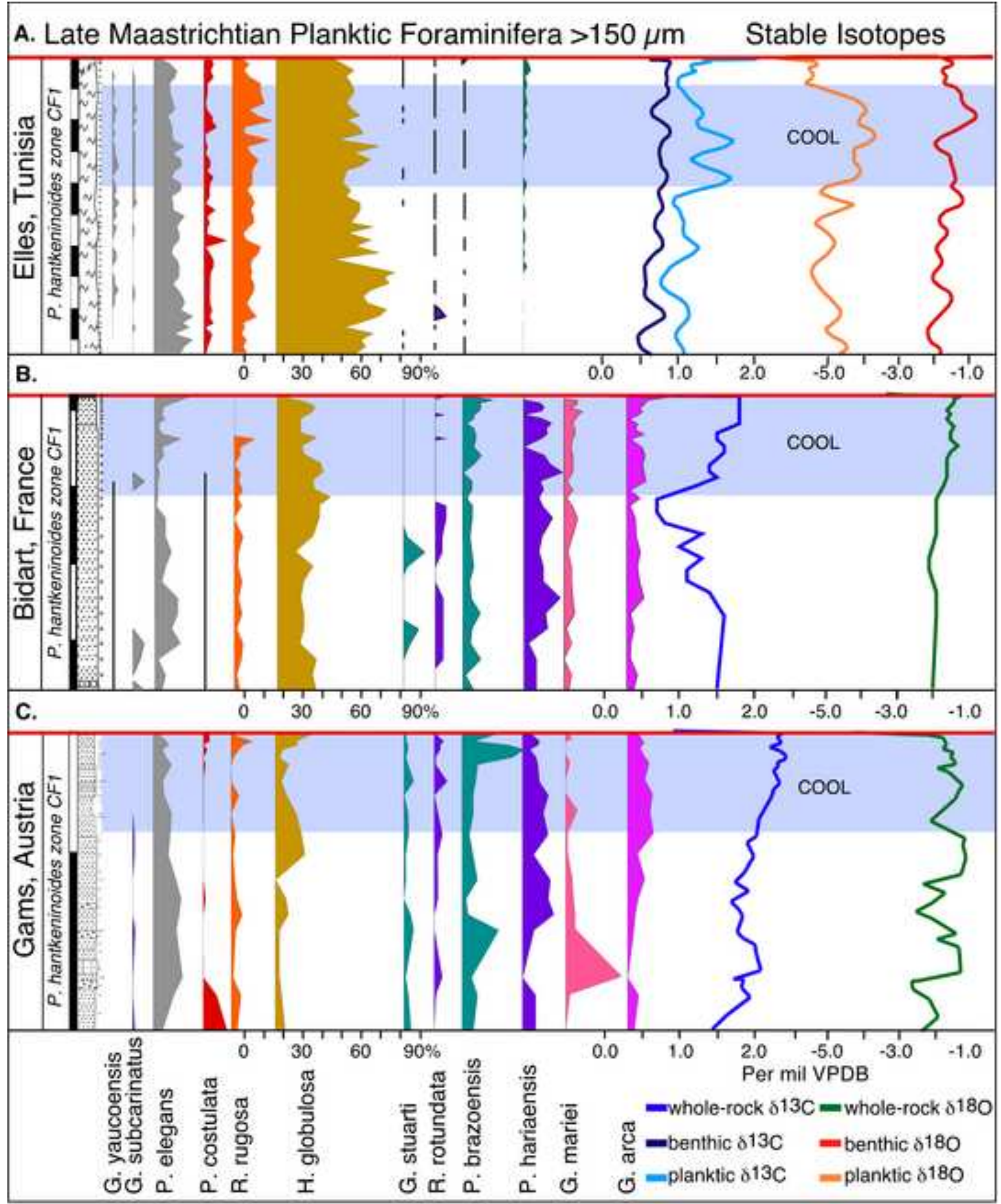


Figure9.ABC. Depth ranked Species

Planktic Foraminifera of different depth-habitats
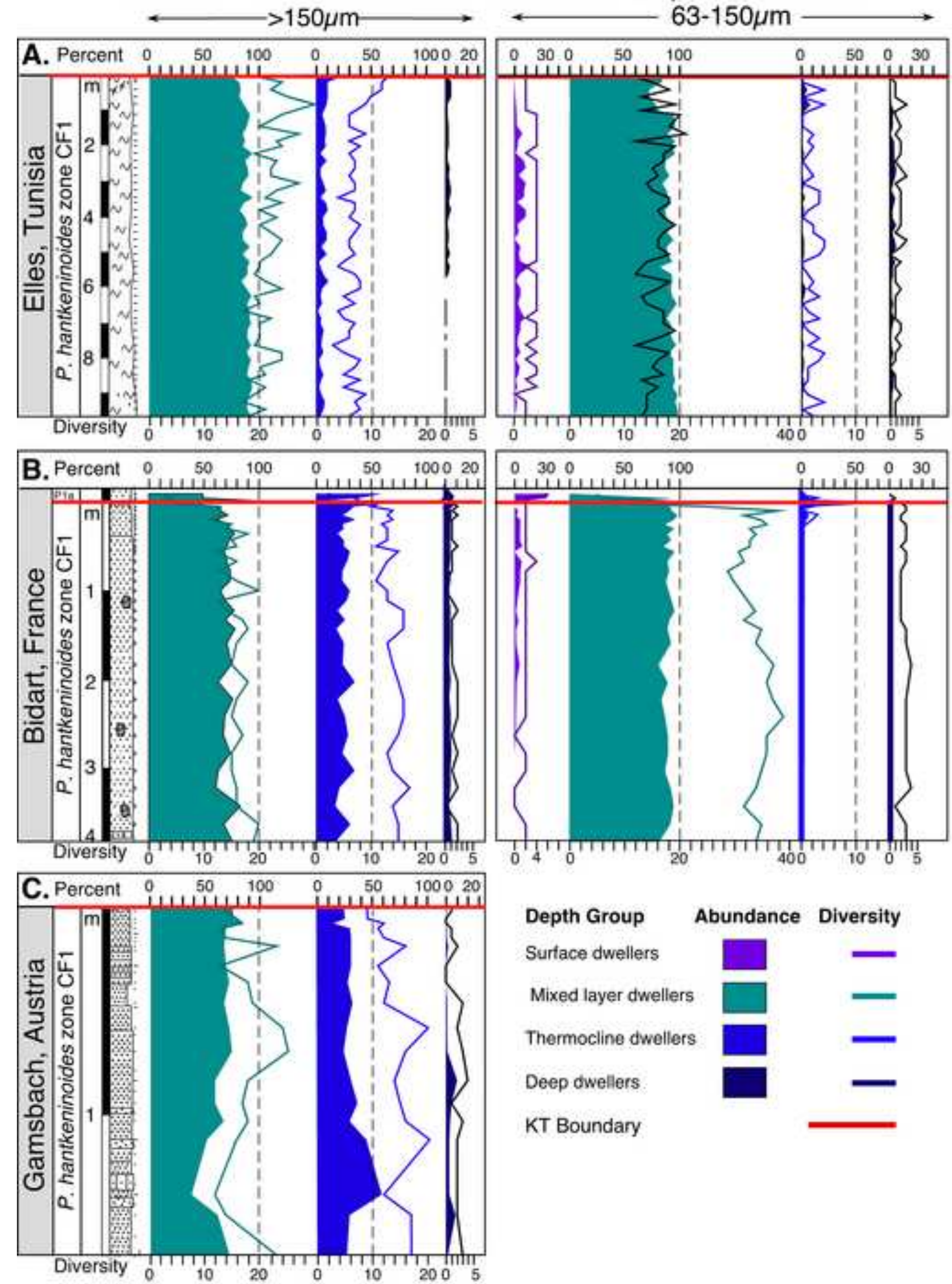

Depth Group Abundance Diversity

Surface dwellers

Mixed layer dwellers

Thermocline dwellers

Deep dwellers

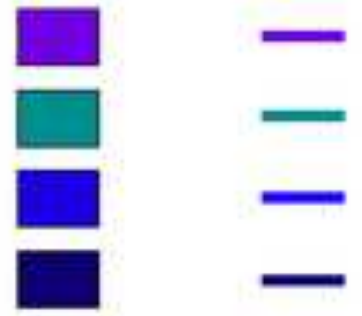

KT Boundary 
Figure10.ABC. Multi-proxy evidence for ocean acidification

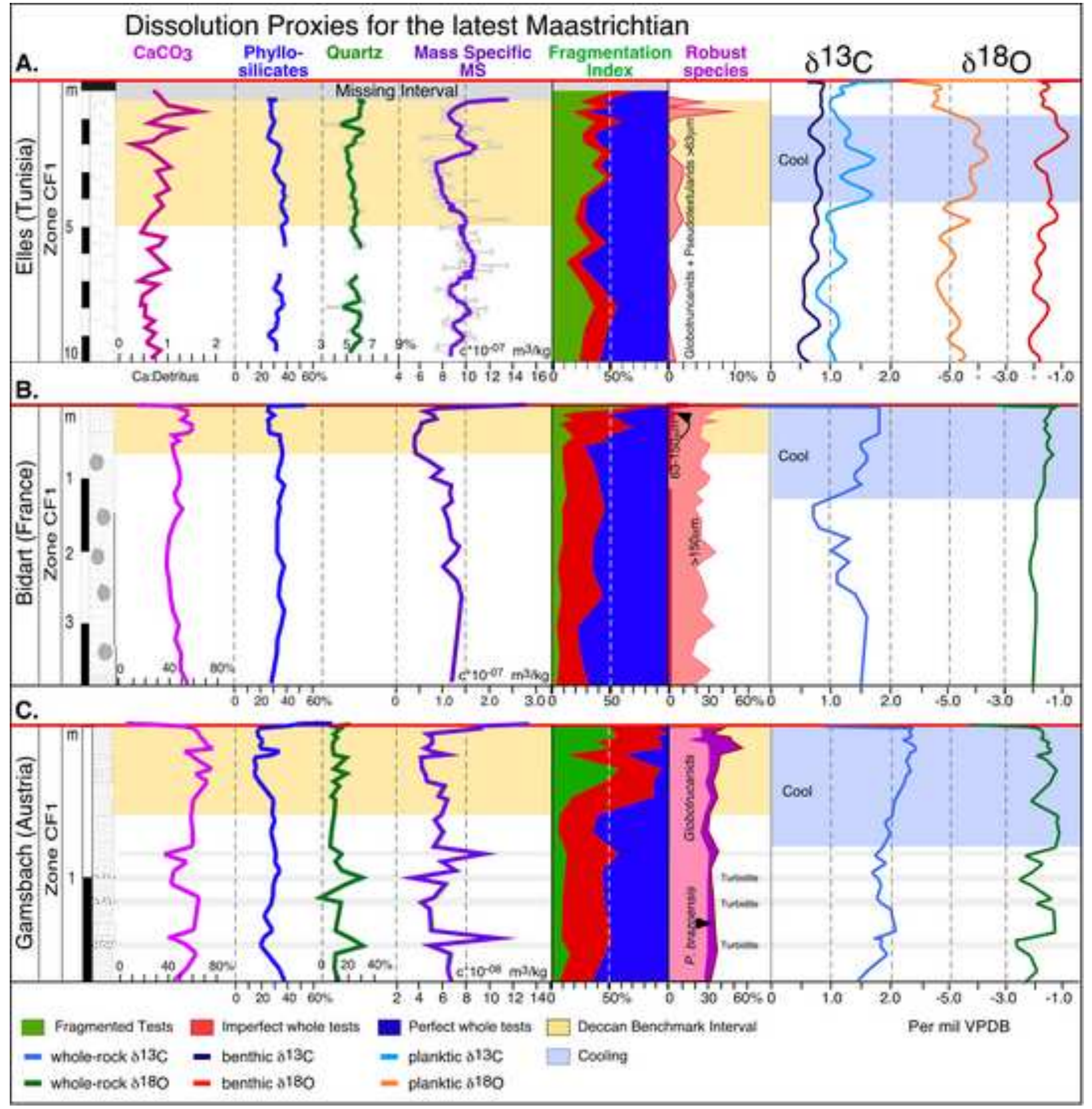




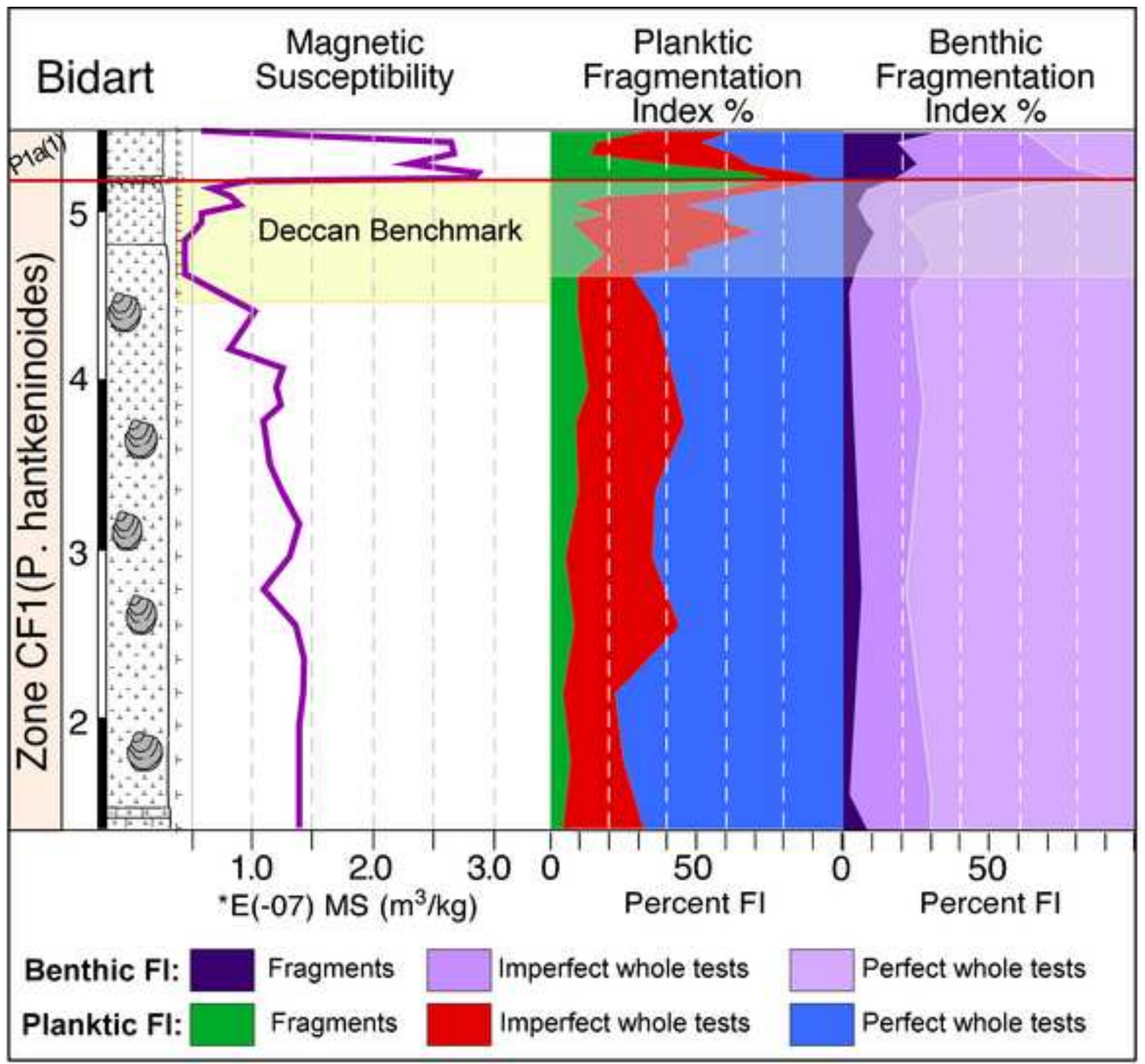




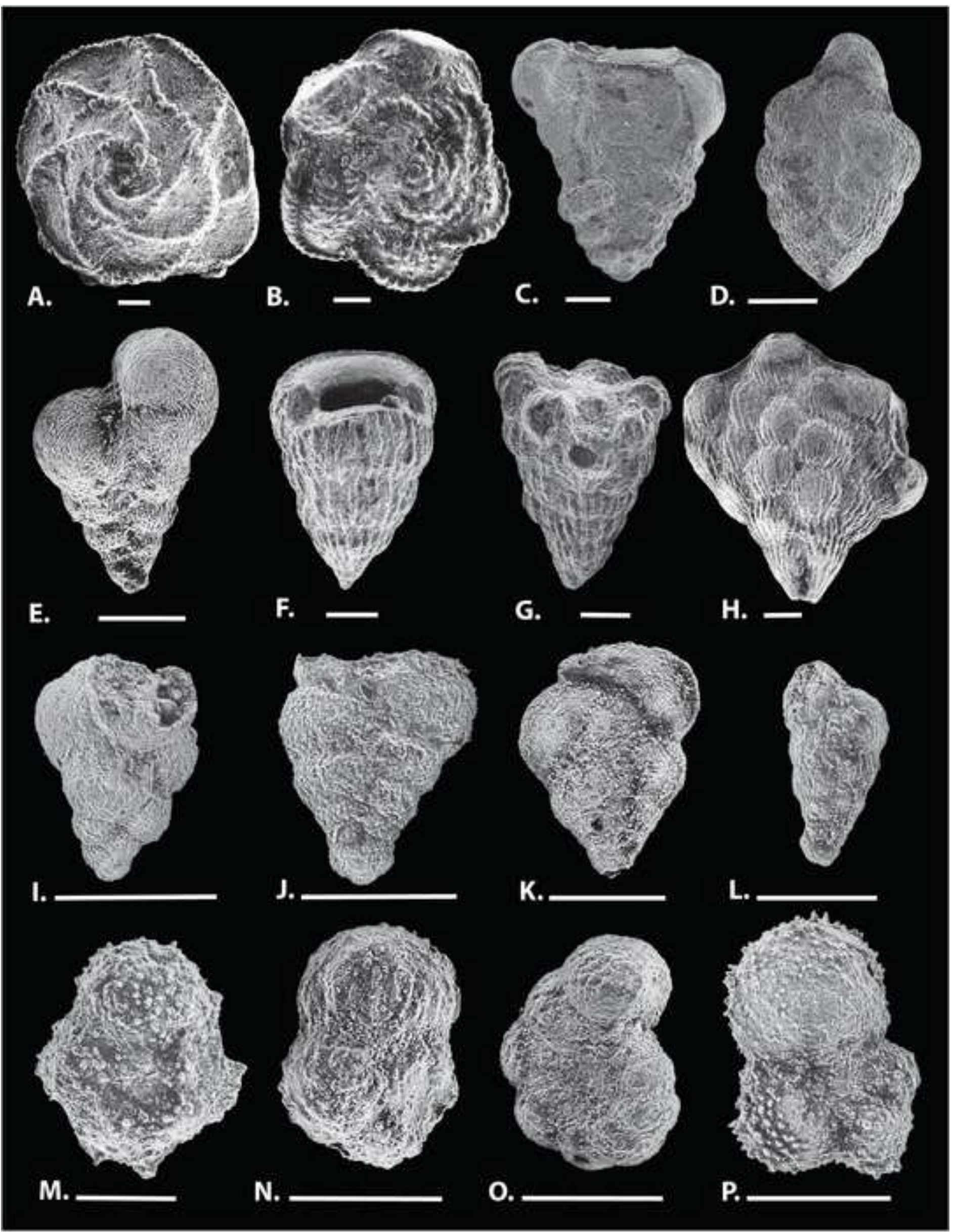



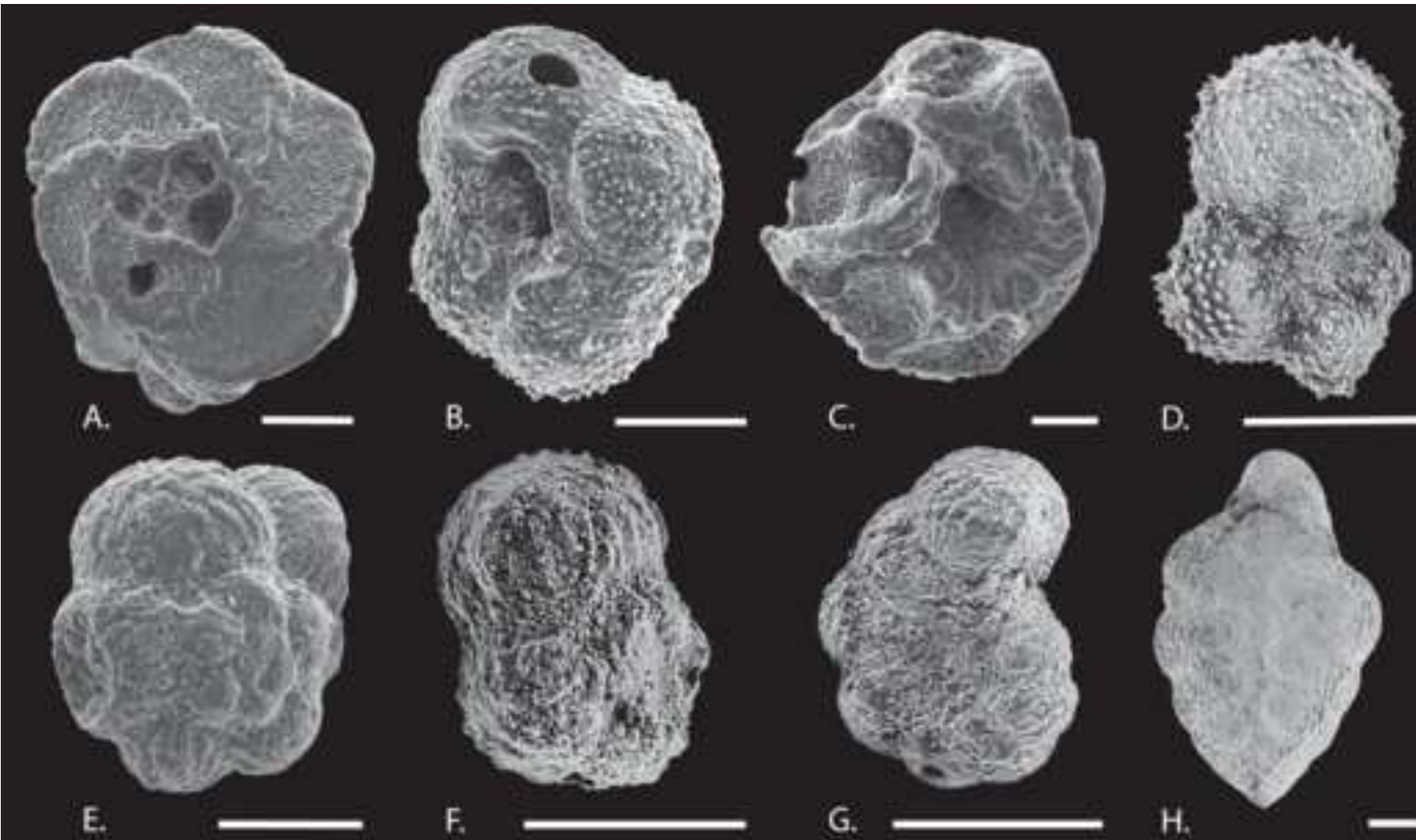

G.

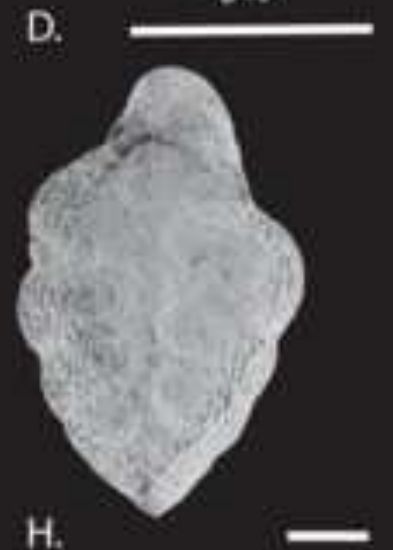

E.
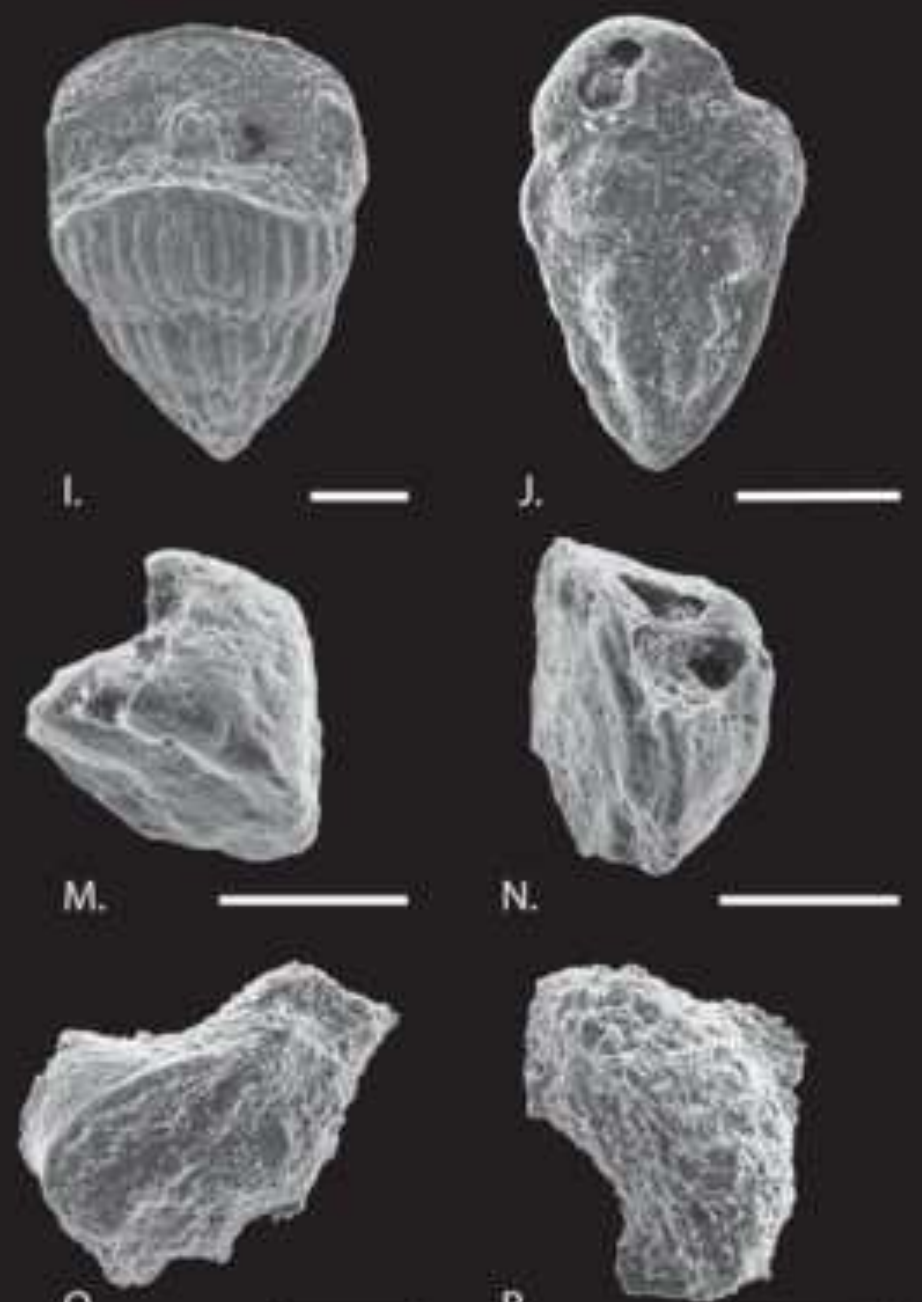

Q.
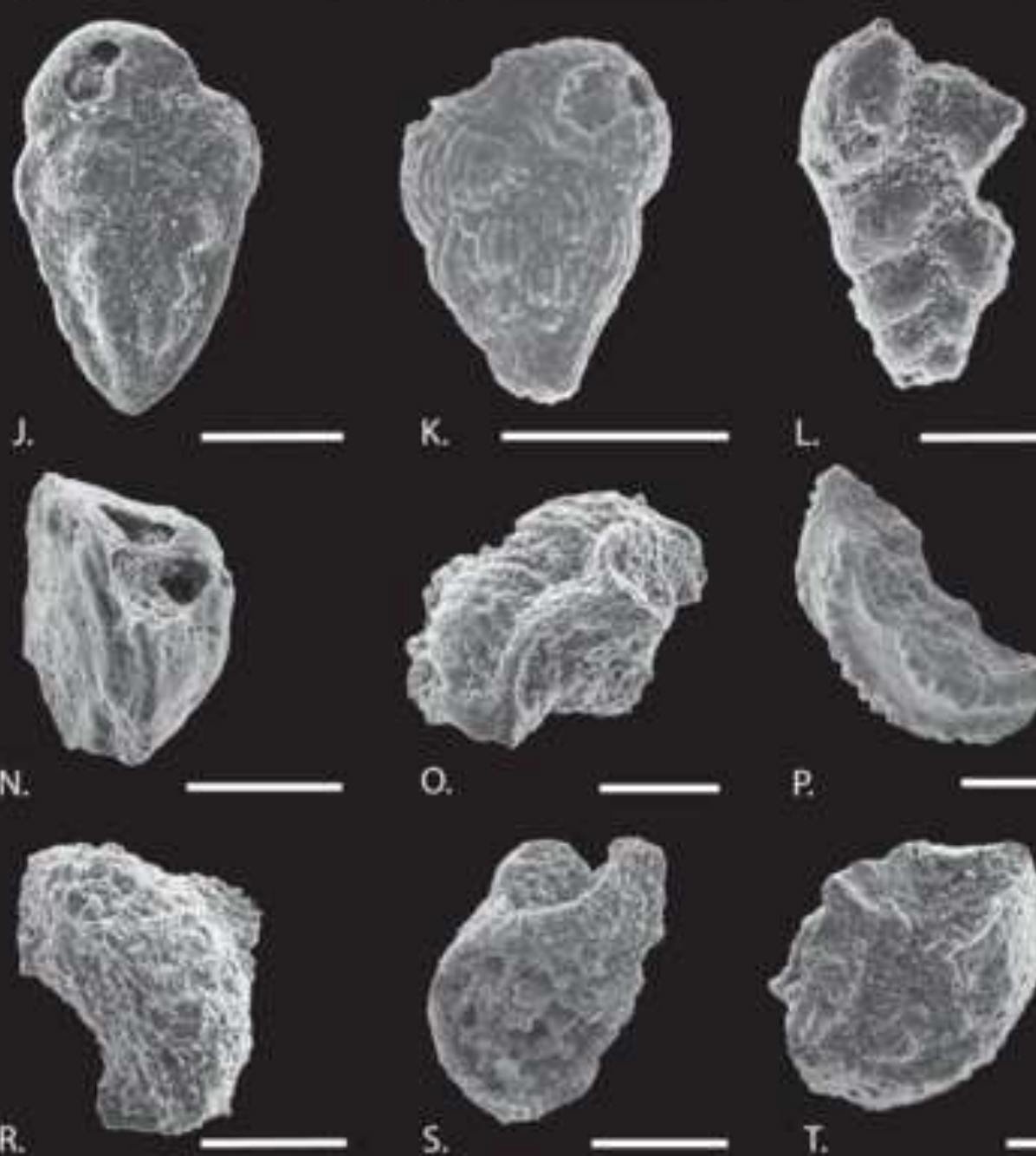

K.

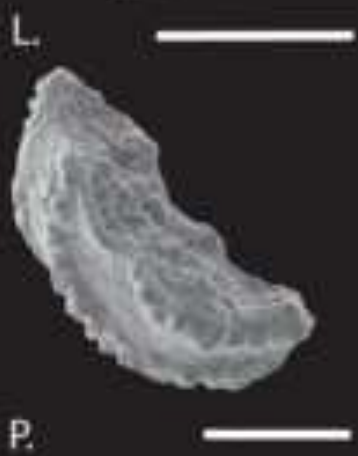

O.
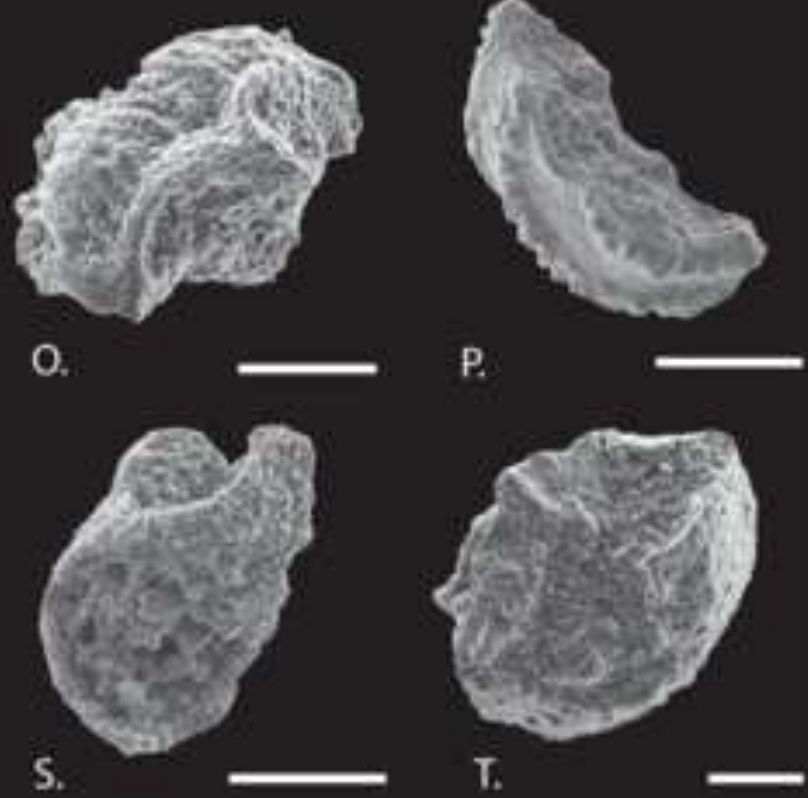


\section{Plate3. Benthic Foraminifera Preservation}

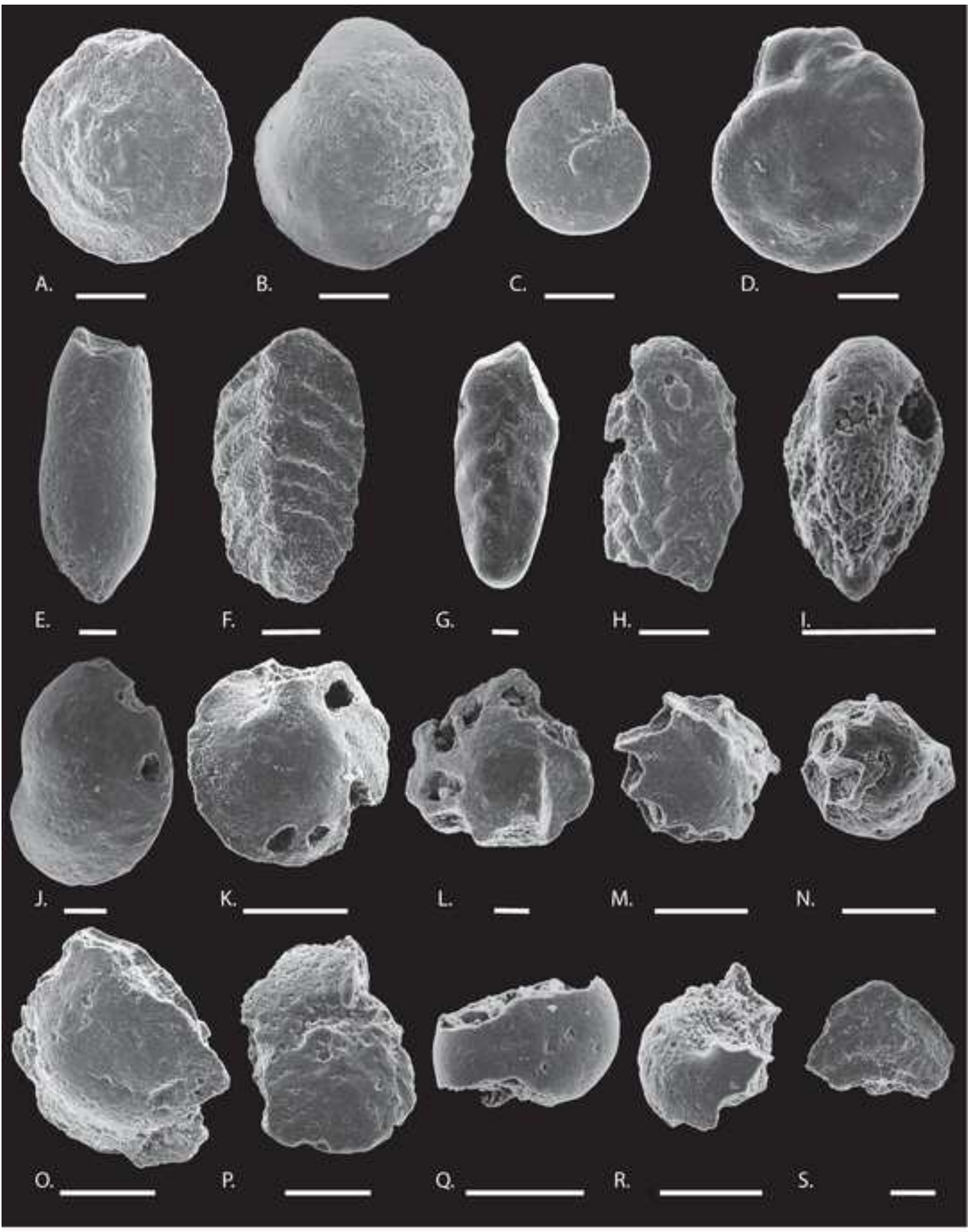

